\title{
The triple oxygen isotope composition of phytoliths as a proxy of continental atmospheric humidity: insights from climate chamber and climate transect calibrations
}

\author{
Anne Alexandre ${ }^{1}$, Amarelle Landais ${ }^{2}$, Christine Vallet-Coulomb $^{1}$, Clément Piel $^{3}$, Sébastien Devidal ${ }^{3}$, \\ Sandrine Pauchet ${ }^{1}$, Corinne Sonzogni ${ }^{1}$, Martine Couapel ${ }^{1}$, Marine Pasturel ${ }^{1}$, Pauline Cornuault ${ }^{1}$, Jingming Xin ${ }^{2}$, \\ Jean-Charles Mazur ${ }^{1}$, Frédéric Prié ${ }^{2}$, Ilhem Bentaleb ${ }^{4}$, Elizabeth Webb ${ }^{5}$, Françoise Chalié ${ }^{1}$, and Jacques Roy ${ }^{3}$ \\ ${ }^{1}$ CEREGE UM34, Aix-Marseille Université, CNRS, IRD, INRA, Aix en Provence, France \\ ${ }^{2}$ Laboratoire des Sciences du Climat et de l'Environnement (LSCE/IPSL/CEA/CNRS/UVSQ), Gif-sur-Yvette, France \\ ${ }^{3}$ Ecotron Européen de Montpellier, UPS 3248, Centre National de la Recherche Scientifique (CNRS), \\ Campus Baillarguet, Montferrier-sur-Lez, France \\ ${ }^{4}$ ISEM, Université de Montpellier, CNRS, IRD, EPHE, Montpellier, France \\ ${ }^{5}$ Department of Earth Sciences, The University of Western Ontario, London, Ontario, Canada
}

Correspondence: Anne Alexandre (alexandre@cerege.fr)

Received: 3 November 2017 - Discussion started: 8 November 2017

Revised: 19 March 2018 - Accepted: 16 April 2018 - Published: 31 May 2018

\begin{abstract}
Continental atmospheric relative humidity (RH) is a key climate parameter. Combined with atmospheric temperature, it allows us to estimate the concentration of atmospheric water vapor, which is one of the main components of the global water cycle and the most important gas contributing to the natural greenhouse effect. However, there is a lack of proxies suitable for reconstructing, in a quantitative way, past changes of continental atmospheric humidity. This reduces the possibility of making model-data comparisons necessary for the implementation of climate models. Over the past 10 years, analytical developments have enabled a few laboratories to reach sufficient precision for measuring the triple oxygen isotopes, expressed by the ${ }^{17} \mathrm{O}$-excess $\left({ }^{17} \mathrm{O}\right.$-excess $\left.=\ln \left(\delta^{17} \mathrm{O}+1\right)-0.528 \times \ln \left(\delta^{18} \mathrm{O}+1\right)\right)$, in water, water vapor and minerals. The ${ }^{17} \mathrm{O}$-excess represents an alternative to deuterium-excess for investigating relative humidity conditions that prevail during water evaporation. Phytoliths are micrometric amorphous silica particles that form continuously in living plants. Phytolith morphological assemblages from soils and sediments are commonly used as past vegetation and hydrous stress indicators. In the present study, we examine whether changes in atmospheric RH imprint the ${ }^{17} \mathrm{O}$-excess of phytoliths in a measurable way and whether this imprint offers a potential for reconstructing past $\mathrm{RH}$. For that purpose, we first monitored the ${ }^{17} \mathrm{O}$-excess evo-
\end{abstract}

lution of soil water, grass leaf water and grass phytoliths in response to changes in $\mathrm{RH}$ (from 40 to $100 \%$ ) in a growth chamber experiment where transpiration reached a steady state. Decreasing RH from 80 to $40 \%$ decreases the ${ }^{17} \mathrm{O}$ excess of phytoliths by 4.1 per meg/\% as a result of kinetic fractionation of the leaf water subject to evaporation. In order to model with accuracy the triple oxygen isotope fractionation in play in plant water and in phytoliths we recommend direct and continuous measurements of the triple isotope composition of water vapor. Then, we measured the ${ }^{17} \mathrm{O}$-excess of 57 phytolith assemblages collected from top soils along a RH and vegetation transect in inter-tropical West and Central Africa. Although scattered, the ${ }^{17} \mathrm{O}$-excess of phytoliths decreases with RH by 3.4 per meg/\%. The similarity of the trends observed in the growth chamber and nature supports that $\mathrm{RH}$ is an important control of ${ }^{17} \mathrm{O}$-excess of phytoliths in the natural environment. However, other parameters such as changes in the triple isotope composition of the soil water or phytolith origin in the plant may come into play. Assessment of these parameters through additional growth chambers experiments and field campaigns will bring us closer to an accurate proxy of changes in relative humidity. 


\section{Introduction}

Continental atmospheric relative humidity (RH) is a key climate parameter. Combined with atmospheric temperature, it allows scientists to estimate the concentration of atmospheric water vapor, which is one of the main components of the global water cycle and the most important gas contributing to the natural greenhouse effect (e.g., Held and Soden, 2000; Dessler and Davis, 2010; Chung et al., 2014). However, global climate models (GCMs) have difficulties in properly capturing continental humidity conditions (Sherwood et al., 2010; Risi et al., 2012; Fischer and Knutti, 2013). Although tropospheric RH results from a subtle balance between different processes (including air mass origins and trajectories, large-scale radiative subsidence, evaporation of falling precipitation, detrainment of convective system, evapotranspiration), it is usually depicted as rather constant in GCMs, in agreement with thermodynamic coupling between atmospheric water vapor and sea surface temperature (Bony et al., 2006; Stevens et al., 2017). A model-data comparison approach is thus essential to progress on this issue. This approach has to be applicable beyond the instrumental period to make use of past changes in atmospheric water vapor conditions.

There are multiple ways to reconstruct past continental temperature and precipitation, for instance from pollen (Bartlein et al., 2010; Herbert and Harrison, 2016; Wahl et al., 2012) or tree ring data (Labuhn et al., 2016; Lavergne et al., 2017). However, there is a serious lack of proxies suitable for reconstructing, in a quantitative way, past variations in continental atmospheric RH. Indeed, the stable isotopes of oxygen and hydrogen $\left(\delta^{18} \mathrm{O}\right.$ and $\left.\delta \mathrm{D}\right)$ of tree rings can be influenced by several parameters other than humidity (precipitation source, temperature). This limits the interpretation of tree ring isotope series in terms of humidity changes to places where variations of these other parameters are well constrained (Grießinger et al., 2016; Wernicke et al., 2015). A promising method relies on the $\delta^{18} \mathrm{O}$ and $\delta D$ of plant biomarkers (e.g., $n$-alkanes and fatty acids from leaf waxes) recovered from soils (or buried soils) and sediments. It allows for an estimate in changes in plant water deuteriumexcess (d-excess $=\delta \mathrm{D}-8.0 \times \delta^{18} \mathrm{O}$ ), linked to changes in precipitation sources and RH. This method under development can however be biased by factors other than climatic ones, such as plant functional types and selective degradation of the biomarkers (e.g., Rach et al., 2017; Schwab et al., 2015; Tuthorn et al., 2015).

Phytoliths are micrometric amorphous silica $\left(\mathrm{SiO}_{2}, \mathrm{nH}_{2} \mathrm{O}\right)$ particles that form continuously in living plants. Silicon is actively absorbed by the roots (Ma and Yamaji, 2006) and is translocated in the plant tissues where it polymerizes inside the cells, in the cell walls and in extracellular spaces of stems and leaves. Silica polymerization appears to be an active physiological process, which does not only depends on transpiration (Kumar et al., 2017). In grasses, which are well known silica accumulators, silica accounts for several \% of dry weight (d.w.) and is mainly located in the stem and leaf epidermis. Phytolith morphological assemblages from soils and sediments are commonly used as past vegetation and hydrous stress indicators (e.g., Aleman et al., 2012; Backwell et al., 2014; Bremond et al., 2005a, b; Contreras et al., 2014; Nogué et al., 2017; Piperno, 2006). The potential of the $\delta^{18} \mathrm{O}$ signature of phytoliths $\left(\delta^{18} \mathrm{O}_{\text {Phyto }}\right)$ from grasses for paleoclimate reconstruction has been investigated through growth chamber and North American Great Plains calibrations. It has been shown that the $\delta^{18} \mathrm{O}_{\text {Phyto }}$ of grass stems weakly affected by transpiration correlated with the $\delta^{18} \mathrm{O}$ signature of soil water $\left(\delta^{18} \mathrm{O}_{\mathrm{SW}}\right)$ and the atmospheric temperature, as expected for a polymerization of silica in isotope equilibrium with the plant water (Webb and Longstaffe, 2000, 2002, $2003,2006)$. It has also been shown that $\delta^{18}$ OPhyto $_{\text {from grass }}$ leaves correlated with RH, as expected for an evaporative kinetic isotope enrichment of the leaf water (e.g., Cernusak et al., 2016) imprinted on $\delta^{18}$ OPhyto. However, because grass stem and leaf phytoliths have the same morphology and are mixed in soil and sedimentary samples, these calibrations were not sufficient for using $\delta^{18} \mathrm{O}_{\text {Phyto }}$ of grassland phytolith assemblages as a paleoclimatic signal. In tropical trees, silica is found in leaves, bark and wood and accounts for a few \% d.w. (e.g., Collura and Neumann, 2017). In the wood, silica polymerizes in the secondary xylem supposedly unaffected by transpiration, in the form of Globular granulate phytolith types (Madella et al., 2005; Scurfield et al., 1974; ter Welle, 1976). These phytoliths make up more than $80 \%$ of tropical humid forest and rainforest phytolith assemblages found in soils and sediments (Alexandre et al., 1997; Alexandre et al., 2012). Examination of the $\delta^{18} \mathrm{O}_{\text {Phyto }}$ of rainforest assemblages showed correlations with the $\delta^{18} \mathrm{O}$ of precipitation $\left(\delta^{18} \mathrm{O}\right.$ Pre $)$ and the atmospheric temperature (Alexandre et al., 2012). However, in this case, the use of $\delta^{18}$ OPhyto did not further develop because it was applicable only to forested areas and humid climatic periods, which is a major drawback for paleoclimatic reconstructions.

The triple isotope composition of oxygen in the water molecule represents an alternative for investigating $\mathrm{RH}$ conditions prevailing during water evaporation. In the triple isotope system, the mass-dependent fractionation factors between $\mathrm{A}$ and $\mathrm{B}\left({ }^{17} \alpha_{\mathrm{A}-\mathrm{B}}\right.$ and $\left.{ }^{18} \alpha_{\mathrm{A}-\mathrm{B}}\right)$ are related by the exponent $\theta_{\mathrm{A}-\mathrm{B}}\left({ }^{17} \alpha_{\mathrm{A}-\mathrm{B}}={ }^{18} \alpha_{\mathrm{A}-\mathrm{B}}^{\theta}\right.$ or $\left.\theta_{\mathrm{A}-\mathrm{B}}=\ln ^{17} \alpha_{\mathrm{A}-\mathrm{B}} / \ln ^{18} \alpha_{\mathrm{A}-\mathrm{B}}\right)$. The exponent can also be expressed as $\theta_{\mathrm{A}-\mathrm{B}}=\Delta^{\prime 17} \mathrm{O}_{\mathrm{A}-\mathrm{B}} / \Delta^{\prime 18} \mathrm{O}_{\mathrm{A}-\mathrm{B}}$ with $\Delta^{\prime 17} \mathrm{O}_{\mathrm{A}-\mathrm{B}}=$ $\delta^{\prime 17} \mathrm{O}_{\mathrm{A}}-\delta^{\prime 17} \mathrm{O}_{\mathrm{B}}, \Delta^{\prime 18} \mathrm{O}_{\mathrm{A}-\mathrm{B}}=\delta^{\prime 18} \mathrm{O}_{\mathrm{A}}-\delta^{\prime 18} \mathrm{O}_{\mathrm{B}}, \delta^{\prime 17} \mathrm{O}=\ln$ $\left(\delta^{17} \mathrm{O}+1\right)$ and $\delta^{\prime 18} \mathrm{O}=\ln \left(\delta^{18} \mathrm{O}+1\right)$. In the $\delta^{\prime 17} \mathrm{O}$ vs. $\delta^{\prime 18} \mathrm{O}$ space, $\lambda_{\mathrm{A}-\mathrm{B}}$ represents the slope of the data alignment during mass-dependent fractionation between $A$ and B. Whereas $\theta_{\mathrm{A}-\mathrm{B}}$ is linked to a particular physical process (equilibrium or kinetic), $\lambda_{\mathrm{A}-\mathrm{B}}$ is empirically measured between two groups of materials and is not related to a wellunderstood single process (Pack and Herwartz, 2014). It 
has been recently estimated that $\theta$ equals 0.529 for liquidvapor equilibrium $\left(\theta_{\text {equil }}\right.$; Barkan and Luz, 2005) and 0.518 for vapor diffusion in air (Barkan and Luz, 2007). It has additionally been shown that meteoric waters plot along a trend with a slope $\lambda$ of $0.528 \pm 0.001$. The departure from this trend is conventionally called ${ }^{17} \mathrm{O}$-excess $\left({ }^{17} \mathrm{O}\right.$ excess $\left.=\delta^{17} \mathrm{O}-0.528 \times \delta^{18} \mathrm{O}\right)($ Luz and Barkan, 2010). In case of mass-dependent fractionation processes, the magnitudes of the ${ }^{17} \mathrm{O}$-excess in waters and minerals are very small and measurement of the ${ }^{17} \mathrm{O}$-excess, expressed in per meg $\left(10^{-3} \%\right.$ o), requires very high analytical precisions.

In the water cycle, the ${ }^{17} \mathrm{O}$-excess variations mainly result from diffusion processes, while equilibrium fractionation does not lead to important departure from the meteoric water mean trend. Theoretical and empirical estimations have shown that in contrast to d-excess, and except at very high latitudes, changes in water ${ }^{17} \mathrm{O}$-excess are not significantly impacted by temperature $\left(\sim 0.1 \mathrm{per} \mathrm{meg} /{ }^{\circ} \mathrm{C}\right.$; Uemura et al., 2010) and much less sensitive to distillation processes (Angert et al., 2004; Barkan and Luz, 2007; Landais et al., 2008; Uemura et al., 2010; Steig et al., 2014). Changes in water ${ }^{17} \mathrm{O}$-excess are thus essentially controlled by evaporative kinetic fractionation. The ${ }^{17} \mathrm{O}$-excess decreases in the evaporating water and increases in the vapor phase when $\mathrm{RH}$ decreases at evaporative sites (e.g., sea surface, lake surface, soil surface or leaf surface). Over the last 10 years, a few studies have used the ${ }^{17} \mathrm{O}$-excess of water to interpret ice core archives in climatic terms (Guillevic et al., 2014, Schoeneman et al., 2014; Winkler et al., 2012; Landais et al., 2008, 2012). They supported that ${ }^{17} \mathrm{O}$-excess is a marker of $\mathrm{RH}$, sea-ice extent at the moisture source, and air mass mixing (Risi et al., 2010) except at the very high latitudes of East Antarctica where temperature can have a significant influence. The observed variations of ${ }^{17} \mathrm{O}$-excess in Greenland ice cores of $\sim 20$ per meg maximum were thus interpreted as variations of $\mathrm{RH}$ or sea-ice extent in the source region and coincide with variations in the low- to mid-latitude water cycle as recorded by other proxies (such as $\mathrm{CH}_{4}$ or $\delta \mathrm{D}$ of $\mathrm{CH}_{4}$ ) (Guillevic et al., 2014). An even smaller number of studies measured or attempted to model the ${ }^{17} \mathrm{O}$-excess of rainwater at low and temperate latitudes (Affolter et al., 2015; Landais et al., 2010b; Li et al., 2015; Luz and Barkan, 2010; Risi et al., 2013). The observed variations in ${ }^{17} \mathrm{O}$-excess, partly explained by convective processes and re-evaporation of precipitation, were on the order of 30-40 per meg, either during a rainy event or along climatic gradients. Only a few studies focused on open surface waters, and showed that variations of the ${ }^{17} \mathrm{O}$-excess ranged from tens to hundreds of per meg when the surface water underwent strong evaporative enrichment (Surma et al., 2015, 2018; Luz and Barkan, 2010), in agreement with the Craig and Gordon (1965) formulation. The most important variations in ${ }^{17} \mathrm{O}$-excess occur at the plant-atmosphere interface. In leaf water, variations higher than 200 per meg were encountered (Landais et al., 2006; Li et al., 2017). Difference in ${ }^{17} \mathrm{O}$-excess between leaf water subject to evaporation (LW) and stem water (SW) not subject to evaporation, increased with decreasing RH (from 100 to $30 \%$ ), as expected for processes dominated by kinetic fractionation. When measuring a sequence of LW-SW couples sampled under different climatic conditions, the slope of the line linking their triple isotope composition and named $\lambda_{\text {transp }}$, equivalent to $\lambda_{\mathrm{LW}-\mathrm{SW}}$, was found to change with RH. This pattern was influenced neither by the plant species nor by the environmental conditions (e.g., atmospheric temperature, soil water conditions) (Landais et al., 2006). However, opposite trends of $\lambda_{\text {transp }}$ with RH were observed from one study to another (Landais et al., 2006; Li et al., 2017). This discrepancy was attributed to the possibility that steady state is not always reached during sampling and to likely differences in isotope composition of the ambient vapor, a parameter of the Craig and Gordon model that is often not measured but estimated (Li et al., 2017).

While ${ }^{17} \mathrm{O}$-excess measurements of waters were expanding, analyses of the triple oxygen isotope composition of minerals (mostly silicates and carbonates) were also developed, allowing estimates of fractionation during polymerization and providing constraints on both temperature and isotope composition of the water source (Pack and Herwartz, 2014; Levin et al., 2014; Passey et al., 2014; Herwartz et al., 2015; Miller et al., 2015; Sharp et al., 2016). Variations of ${ }^{17} \mathrm{O}$-excess on the order of tens to hundreds of per meg were reported from one mineral to another. For most of the studies cited above, the objective was to discriminate between high and low temperature formation processes or to decipher from which type of water the mineral formed (i.e., seawater, hydrothermal water, meteoric or surface water). The ${ }^{17} \mathrm{O}$-excess of biogenic and sedimentary carbonates was also investigated as a potential record of evaporating water sources (Passey et al., 2014). With regard to silicate-water fractionation, the relationship between the three oxygen isotopes defined by

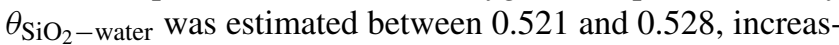
ing logarithmically with temperature (Sharp et al., 2016).

In the present study, in the light of the recent findings cited above, we examined whether changes in atmospheric RH imprint the ${ }^{17} \mathrm{O}$-excess of phytoliths $\left({ }^{17} \mathrm{O}\right.$-excess Phyto $)$ in a measurable way and whether this imprint offers a potential for reconstructing past RH. For that purpose, we first monitored the ${ }^{17} \mathrm{O}$-excess evolution of soil water, grass leaf water and grass phytoliths in response to changes in $\mathrm{RH}$ in a growth chamber experiment. Then, we measured the ${ }^{17} \mathrm{O}$-excess Phyto from 57 phytolith assemblages collected in soil tops along a $\mathrm{RH}$ and vegetation transect in inter-tropical West and Central Africa. Relationships between ${ }^{17} \mathrm{O}$-excessphyto and $\mathrm{RH}$ were looked for and assessed on the basis of previous quantifications of kinetic isotope enrichment of leaf water and equilibrium fractionation between water and silica. Results from the natural sampling were compared to the ones from the growth chamber experiment to evaluate the importance of $\mathrm{RH}$ in controlling ${ }^{17} \mathrm{O}$-excess Phyto in natural environment. 


\section{Materials and methods}

\subsection{Samples from the growth chamber experiment}

Festuca arundinacea, commonly referred to as tall fescue, is widely distributed globally as forage and an invasive grass species (Gibson and Newman, 2001) and can adapt to a wide range of conditions. In 2016, $F$. arundinacea (Callina RAGT Semences) was grown in three chambers under three conditions of RH (ca. 40, 60 and $80 \%$ ) kept constant using wet air introduction and ultrasonic humidifier. We checked that the humidifiers did not lead to any isotope fractionation between the water in their reservoirs and the vapor delivered. Temperature and light intensity were kept constant at $25 \pm 0.6$ (standard deviation, SD) ${ }^{\circ} \mathrm{C}$ and $293 \pm 14$ (SD) $\mathrm{mmol} \mathrm{m}^{-2} \mathrm{~s}^{-1}$, respectively.

In a $35 \mathrm{~L}$ tank $(53 \times 35 \times 22 \mathrm{~cm}), 20 \mathrm{~kg}$ of dried commercial potting soil were packed above a $1.6 \mathrm{~cm}$ layer of quartz gravel. A porous cup for water extraction was placed in the soil with its extraction tube hermetically extending outside of the tank walls. The soil was irrigated with $10 \mathrm{~L}$ of the same water as the one used for the humidifier. Four grams of seeds were sown along four rows in each tank, resulting in about 6000 seedlings. Each tank was then placed in a chamber and was irrigated from a Mariotte bottle $(25 \mathrm{~L})$ placed next to it. The Mariotte system was set so that a water saturated level of $5 \mathrm{~cm}$ remained constant at the base of the tank. The irrigation water was supplemented with $105 \mathrm{mg} \mathrm{L}$ of $\mathrm{SiO}_{2}$ (in the form of $\mathrm{SiO}_{2} \mathrm{~K}_{2} \mathrm{O}$ ). Ten days after germination, agaragar (polysaccharide agarose) was spread on the soil surface around the seedlings (about $8 \mathrm{~cm}$ tall), to prevent any evaporation (Alexandre et al., 2016).

A fourth tank was kept at $100 \%$ of RH thanks to the installation of a $20 \mathrm{~cm}$ high plexiglass cover, in a forth chamber set at $80 \%$ of RH. In this case no agar-agar was added and the vapor around $F$. arundinacea came from evaporation and transpiration of the soil water. Otherwise the treatment was the same as in the other chambers.

For each humidity condition, three to four harvests were made at intervals of 10-14 days. The $20-25 \mathrm{~cm}$ long leaves were cut at two $\mathrm{cm}$ above the soil level and weighed. From the first to the fourth sampling, the harvested wet leaves increased from 15-20 g (10 days of growth) to 40-60 g (14 days of growth). Three to five $g$ of leaves were put in glass gastight vials and kept frozen for bulk leaf water extraction. The remaining leaves were dried for phytolith extraction. Forty $\mathrm{mL}$ of irrigation water from the Mariotte bottle, and of soil water from the porous cup, were kept at $5{ }^{\circ} \mathrm{C}$ before analyses.

After each harvest, the tanks were left in their chamber of origin but the 40,60 and $80 \% \mathrm{RH}$ treatments were rotated between the growth chambers so that the four replicates of a given RH treatment would come from at least two different chambers. The $100 \%$ humidity was set up in a unique chamber during the entire duration of the experiment. The har- vested leaves in this treatment were often covered by condensation drops which were blotted between two sheets of wiping paper, rapidly after harvesting. The experimental setup details and the harvest list are given in Table 1.

\subsection{Samples from the natural climate transects}

Fifty-seven top soil samples were collected during several field trips along vegetation and humidity transects in Mauritania and Senegal (Bremond et al., 2005b; Lézine, 1988; Pasturel, 2015) Gabon (Lebamba et al., 2009) and Congo (Alexandre et al., 1997) in the Saharan, Sahelian, Sudanian, guinean and Congolian bioclimatic zones, respectively (White et al., 1983). Samplings, phytolith extractions and phytolith morphological assemblages descriptions are given in the above-mentioned studies, except for the samples of Gabon from which phytoliths were chemically treated and counted in the frame of the present study.

The sampled site location as well as the associated climatic and oxygen isotope variables are given in Table 2 . The vegetation overlying the sampled soils was categorized into savanna (Mauritania, Senegal), wooded savanna (Senegal), humid forest (Gabon and Congo) and enclosed savanna (Gabon). For each sampled site, yearly climate average were calculated from the monthly means of temperature, precipitation, RH and diurnal temperature, extracted from the Climate Research Unit (CRU) 1961-1990 time series (10' spatial resolution; http://www.cru.uea.ac.uk (last access: 23 May 2018), Harris et al., 2013, CRU 2.0). Mean annual precipitation (MAP), mean annual temperature (MAT) and mean annual $\mathrm{RH}$ range from 49 to $2148 \mathrm{~mm}, 24.3$ to $29.8^{\circ} \mathrm{C}$ and 40.2 to $82.5 \%$, respectively. In addition, in order to get a proxy of RH during wet months, likely those of the grass growing season, averaged RH monthly means for months with at least 1 day with precipitation higher than $0.1 \mathrm{~mm}(\mathrm{RH}-\mathrm{rd0}>1)$ was calculated. It ranges from 56.3 to $82.5 \%$. As maximum transpiration is supposed to be reached around 15:00 UTC we also calculated RH and RH-rd0 > 1 at 15:00 (RH15 and RH15-rd0 > 1, respectively) according to New et al. (2002) and Kriticos et al. (2012). For each sampling site, estimates of $\delta^{\prime 18} \mathrm{O}$ of precipitation for the months with at least 1 day with precipitation higher than $0.1 \mathrm{~mm}\left(\delta^{\prime 18} \mathrm{O}_{\mathrm{Pre}-\mathrm{rd} 0>1}\right)$ were calculated from $\delta^{18} \mathrm{O}$ of precipitation extracted from The Online Isotopes in Precipitation Calculator-version OIPC22 (http://www.waterisotopes.org (last access: 23 May 2018); Bowen and Revenaugh, 2003; Bowen and Wilkinson, 2002; Bowen et al., 2005) and weighted by the amount of precipitation. The estimates range from -1.51 to $-4.46 \%$. There is currently no data on the ${ }^{17} \mathrm{O}$-excess of precipitation $\left({ }^{17} \mathrm{O}\right.$ excesspre) at these sites. 


\subsection{Phytolith chemical extractions}

Phytoliths from soils were extracted following Crespin et al. (2008) using $\mathrm{HCl}, \mathrm{H}_{2} \mathrm{O}_{2}, \mathrm{C}_{6} \mathrm{H}_{5} \mathrm{Na}_{3} \mathrm{O}_{7}$ and $\mathrm{Na}_{2} \mathrm{O}_{4} \mathrm{~S} 3-$ $\mathrm{H}_{2} \mathrm{O}$ at $70^{\circ} \mathrm{C}$, and a $\mathrm{ZnBr}_{2}$ heavy liquid separation. It has been shown that up to a temperature of $70^{\circ} \mathrm{C}$ the extraction has no effect on the $\delta^{18} \mathrm{O}$ (Crespin et al., 2008). We verified that it did not have any effect on the ${ }^{17} \mathrm{O}$-excess either, using our internal standard MSG extracted at 60 and $70^{\circ} \mathrm{C}$ (Crespin et al., 2008). The obtained ${ }^{17} \mathrm{O}$-excess values were similar ( -211 and -243 per meg, respectively) given our reproducibility of \pm 34 per meg (see Sect. 2.6.1). Phytoliths from Festuca arundinaceae were thus extracted using a high purity protocol with $\mathrm{HCl}, \mathrm{H}_{2} \mathrm{SO}_{4}, \mathrm{H}_{2} \mathrm{O}_{2}, \mathrm{HNO}_{3}, \mathrm{KClO}_{3}$ and $\mathrm{KOH}$ at $70^{\circ} \mathrm{C}$ following Corbineau et al. (2013).

\subsection{Phytolith counting}

Phytolith assemblages from the humidity transects were mounted on microscope slides in Canada Balsam, for counting, at a $600 \times$ magnification. More than 200 identifiable phytoliths with a diameter greater than $5 \mu \mathrm{m}$ and with a taxonomic significance were counted per sample. Three repeated counting gave an error of $\pm 3.5 \%$ (SD). Phytoliths were named using the International Code for Phytolith Nomenclature 1.0 (Madella et al., 2005) and categorized as Globular granulate type produced by the wood (Scurfield et al., 1974; Kondo et al., 1994), palm Globular echinate type and grass types comprising Acicular, Bulliform, Elongate psilate, Elongate echinate, Bulliform cells, and Grass Short Cells types. For each sample from the natural transects, the phytolith index $d / p$, a proxy of tree cover density (Alexandre and Bremond, 2009; Bremond et al., 2005b), was calculated. It is the ratio of Globular granular phytolith category (Madella et al., 2005) formed in the secondary xylem of the dicotyledon $(d)$ wood to the grass short cell phytolith category formed in the epidermis of grasses or Pooideae (p) (Collura and Neumann, 2017; Scurfield et al., 1974; ter Welle, 1976). Those two categories make up most of the phytolith assemblages recovered from inter-tropical soils (Bremond et al., 2005a, b; Alexandre et al., 1997, 2013).

Phytolith assemblages from the $F$. arundinacea samples were also mounted and counted. The phytolith types were categorized according to their cell of origin in the epidermis into Epidermal short cell, Epidermal long cell, Bulliform cell and Hair acicular.

\subsection{Leaf and soil water extraction}

Leaf water was extracted using a distillation line. Leaves were introduced in a glass tube connected to the distillation line, and frozen through immersion of the glass tube in liquid nitrogen. While keeping the sample frozen, the distillation line was pumped to reach a vacuum higher than $5 \times 10^{-2}$ mbar. The pumping system was then isolated and the glass sample tube warmed to $80^{\circ} \mathrm{C}$. Meanwhile, at the other end of the distillation line, a glass collecting tube was immersed in liquid nitrogen to trap the extracted water. To avoid condensation, the line between the sample tube and the collection tube was heated with a heating wire. The distillation was completed after $6 \mathrm{~h}$. In order to remove volatiles from the extracted water, a few granules of activated charcoal were added and the water slowly stirred for $12 \mathrm{~h}$.

Soil water was extracted using a $31 \mathrm{~mm}$ porous ceramic cup. Brown- or yellow-colored samples were filtered at $0.22 \mu \mathrm{m}$, but remained colored after filtration, indicating the presence of soluble compounds.

\subsection{Isotope analyses}

The oxygen isotope results are expressed in the standard $\delta$ notation relative to VSMOW.

\subsubsection{Phytoliths}

Phytolith samples of $1.6 \mathrm{mg}$ were dehydrated and dehydroxylated under a flow of $\mathrm{N}_{2}$ (Chapligin et al., 2010) and oxygen extraction was performed using the IR Laser-Heating Fluorination Technique at CEREGE (Aix-en-Provence, France) (Alexandre et al., 2006; Crespin et al., 2008; Suavet et al., 2010). The purified oxygen gas $\left(\mathrm{O}_{2}\right)$ was passed through a $-114{ }^{\circ} \mathrm{C}$ slush to refreeze gases interfering with the mass 33 (e.g., NF), potentially produced during the fluorination of residual organic $\mathrm{N}$, before being sent to the dual-inlet mass spectrometer (ThermoQuest Finnigan Delta Plus). The composition of the reference gas was determined through the analyses of NBS28 for which isotope composition has been set to $\delta^{18} \mathrm{O}=9.60 \%, \delta^{17} \mathrm{O}=4.99 \% \circ$ and ${ }^{17} \mathrm{O}$-excess $=-65$ per meg. During the measurement period, reproducibility (SD) of the analyses of the working quartz standard (Boulangé 2008) against which the isotope composition of the sample gas was corrected on a daily basis (three quartz standards were analyzed per day) was $\pm 0.20 \%, \pm 0.11 \%$ 。 and \pm 22 per meg for $\delta^{18} \mathrm{O}, \delta^{17} \mathrm{O}$ and ${ }^{17} \mathrm{O}$-excess, respectively ( $n=63$; one run of eight dual inlet measurements). For every session of measurement, the effectiveness of the entire dehydration and IR-laser-fluorination-IRMS procedure was checked through the analysis of a working phytolith standard (MSG60) with $\delta^{18} \mathrm{O}=36.90 \pm 0.78 \% \circ, \delta^{17} \mathrm{O}=19.10 \pm$ $0.40 \%$ and ${ }^{17} \mathrm{O}$-excess $=-215 \pm 34$ per meg $(n=29)$. For comparison, the inter-laboratory pooled value for MSG60 is $\delta^{18} \mathrm{O}=37.0 \pm 0.8 \%$ o (Chapligin et al., 2011). Recent measurements of the silicate reference materials UWG-2 garnet (Valley et al., 1995) and San Carlos (SC) olivine gave the following values: $\delta^{18} \mathrm{O}_{\text {UWG-2 }}=5.72 \pm 0.12 \%, \delta^{17} \mathrm{O}_{\text {UWG-2 }}=$ $2.95 \pm 0.06 \%,{ }^{17} \mathrm{O}$-excessuWG-2 $=-68 \pm 27$ per meg $(n=$ $5), \delta^{18} \mathrm{O}_{\mathrm{SC}}=4.95 \pm 0.22 \% o, \delta^{17} \mathrm{O}_{\mathrm{SC}}=2.56 \pm 0.12 \%,{ }^{17} \mathrm{O}-$ excesssC $=-49 \pm 24$ per meg $(n=3)$. For comparison, silicate analyses presented in Sharp et al. (2016) are normalized to a $\delta^{18} \mathrm{O}$ value for San Carlos Olivine of $5.3 \%$ and a 
${ }^{17} \mathrm{O}$-excess value of -54 per meg. As previously discussed in Suavet et al. (2010), a large scatter is often observed for SC olivine $\delta^{18} \mathrm{O}$ and $\delta^{17} \mathrm{O}$ values measured in a given laboratory or from a laboratory to another. This is probably attributable to the heterogeneity of the analyzed samples. At CEREGE, the internal standard of SC olivine is prepared from a number of millimetric crystals with possibly different oxygen isotope composition. The $\delta^{18} \mathrm{O}$ and $\delta^{17} \mathrm{O}$ values from Suavet et al. (2010), Tanaka and Nakamura (2013), Pack et al. (2016), Sharp et al. (2016) and the present study average $5.29 \pm 0.23$ (1 SD) \%o and $2.72 \pm 0.12$ (1 SD) \%o, respectively. Nevertheless, despite the large $\mathrm{SD}$ on ${ }^{18} \mathrm{O}$ and $\delta^{17} \mathrm{O}$ measurements, the $\mathrm{SC}$ olivine ${ }^{17} \mathrm{O}$-excess appears relatively constant $(-71 \pm 23$ (1 SD)) per meg.

\subsubsection{Leaf water}

Leaf water was analyzed at LSCE (Gif-sur-Yvette, France) following the procedure previously detailed in Landais et al. (2006). In summary, a fluorination line was used to convert water to oxygen using $\mathrm{CoF}_{3}$ heated at $370{ }^{\circ} \mathrm{C}$ in a helium flow. The oxygen was then trapped in a tube immersed in liquid helium before being analyzed by dual inlet IRMS (ThermoQuest Finnigan MAT 253 mass spectrometer) against a reference oxygen gas. All measurements were run against a working $\mathrm{O}_{2}$ standard calibrated against VSMOW. The resulting precisions ( 2 runs of 24 dual inlet measurements) were $0.015 \%$ or $\delta^{17} \mathrm{O}, 0.010 \%$ for $\delta^{18} \mathrm{O}$ and 5 per meg for ${ }^{17} \mathrm{O}$ excess.

\subsubsection{Irrigation and soil waters}

Irrigation and soil water were analyzed at the Ecotron of Montpellier (France) with an isotope laser analyzer (Picarro L2140i) operated in ${ }^{17} \mathrm{O}$-excess mode using an auto-sampler and a high-precision vaporizer. Each water sample was used to fill three vials randomly dispatched in four groups of six samples (three replicates per sample). Each sample group was bracketed by three working standards (Giens-1, Iceberg1 and Eco-1). Ten injections were performed for each vial, and the results of the first six injections were discarded to account for memory effects. Following IAEA recommendations (IAEA, 2013), each liquid measurement sequence was started with two vials of deionized water for instrument conditioning.

The isotope compositions of each sample group were calibrated using the three interpolated mean values obtained for the bracketing working standards (Delattre et al., 2015). All isotope ratios were normalized on the VSMOW2/SLAP2 scale, with an assigned SLAP $2{ }^{17} \mathrm{O}$-excess value of zero, following the recommendations of Schoenemann et al. (2013). The resulting precisions (three replicates) were $0.02 \%$, $0.01 \%$ and 10 per meg for $\delta^{17} \mathrm{O}, \delta^{18} \mathrm{O}$ and ${ }^{17} \mathrm{O}$-excess $(n=31)$.
The three working standards were also analyzed using the fluorination/IRMS technique used for leaf water analyses at LSCE. The ${ }^{17} \mathrm{O}$-excess maximum difference was 6.4 per meg, which is lower than the analytical precision obtained using the laser spectrometer (Table S1a in the Supplement).

In order to assess whether soluble organic compounds present in some soil water samples did not impact the laser analyzer isotope measurements (Martín-Gómez et al., 2015), a representative set of colored samples were analyzed with and without the Picarro micro combustion module (MCM) set up between the high-precision vaporizer and the analyzer inlet. This system was designed to partly remove organic volatile compounds using a catalytic process. The obtained isotope compositions were not significantly different (Table S1b), suggesting that organic compounds were either in low concentration, and/or did not interfere in the spectral window used by the analyzer. Therefore, the other soil water samples were analyzed without the MCM.

\section{Results}

\subsection{Growth chamber experiment}

$\delta^{\prime 18} \mathrm{O}$ and ${ }^{17} \mathrm{O}$-excess of the irrigation water (respectively $\delta^{\prime 18} \mathrm{O}_{\text {IW }}$ and ${ }^{17} \mathrm{O}$-excess $\mathrm{IW}$ ) average $-5.59 \pm 0.00 \%$ and $26 \pm 5$ per meg, respectively. $\delta^{\prime 18} \mathrm{O}$ and ${ }^{17} \mathrm{O}$-excess of the soil water (respectively $\delta^{\prime 18} \mathrm{O}_{\mathrm{SW}}$ and ${ }^{17} \mathrm{O}$-excess $\mathrm{SW}$ ) average $-2.89 \pm 0.19 \%$ and $16 \pm 8$ per meg, respectively (Table S2). The isotope difference is thus significant for $\delta^{\prime 18} \mathrm{O}$, less significant for ${ }^{17} \mathrm{O}$-excess, according to the analytical error. Although evaporative kinetic fractionation of the top soil water suctioned by the porous cup under vacuum cannot be ruled out, isotopic exchanges between the soil water and oxygenbearing phases of the rhizosphere may also have impacted the soil water isotopic composition (Bowling et al., 2017; Chen et al., 2016; Oerter et al., 2014; Orlowski et al., 2016). Hereinafter, we consider the isotope signatures of the water absorbed by the roots of $F$. arundinacea to be equivalent to the irrigation water that fed the saturation level at the base of the tank. This water was reached by the deepest roots, as observed on a cross section of the soil after the end of the experiment, and likely reached the upper roots by capillarity.

The transpiration of $F$. arundinacea increases rapidly from 0.03 to $0.6 \mathrm{~L} \mathrm{day}^{-1}$ from 100 to $60 \% \mathrm{RH}$ and more slowly from 60 to $40 \% \mathrm{RH}$, where it reaches $0.61 \mathrm{~L} \mathrm{day}^{-1}$ (averages of the replicates, Table 1). In response to decreasing $\mathrm{RH}, \delta^{\prime 18} \mathrm{O}$ (Table S2) and ${ }^{17} \mathrm{O}$-excess (Fig. 1a) values of the bulk leaf water $\left(\delta^{\prime 18} \mathrm{O}_{\mathrm{LW}}\right.$ and ${ }^{17} \mathrm{O}$-excess $\left.\mathrm{LW}\right)$ show clear increasing and decreasing trends, respectively. The averaged ${ }^{18} \mathrm{O}$-enrichment of bulk leaf water relatively to irrigation water $\left(\Delta^{\prime 18} \mathrm{O}_{\mathrm{LW}-\mathrm{IW}}\right)$ increases from 100 to $60 \%$ of $\mathrm{RH}$ and seems to be stabilizing from 60 to $40 \%$ RH (Fig. 1b; Table 1). For $100 \% \mathrm{RH}$, the high standard deviations (SD) associated with $\delta^{18} \mathrm{O}_{\mathrm{LW}}$ (Table S2), and consequently with 

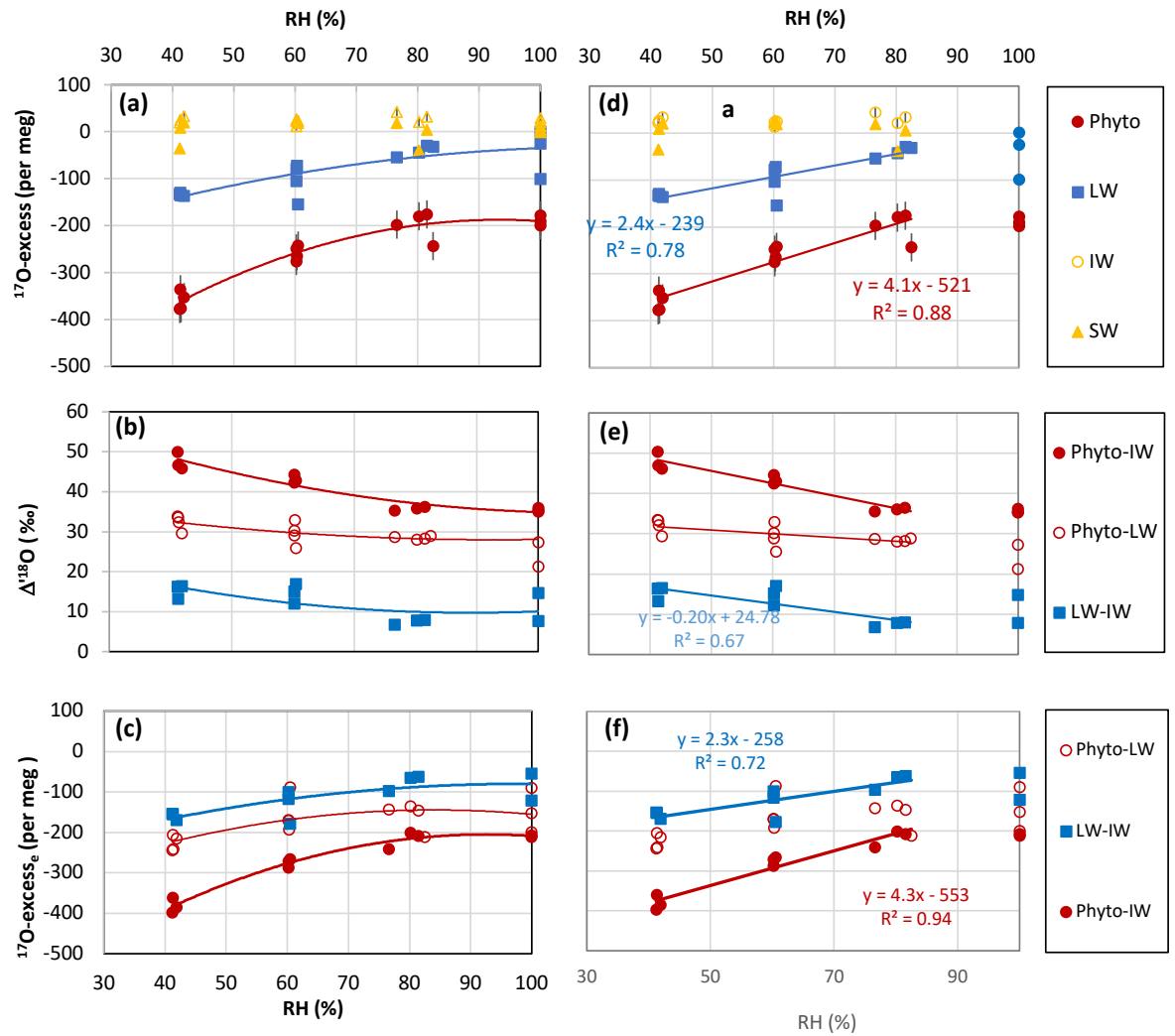

Figure 1. Growth chamber experiment: (a) ${ }^{17} \mathrm{O}$-excess vs. relative humidity (RH) of irrigation water (IW), soil water (SW), leaf water (LW) and phytolith (Phyto). Error bars show standard deviation (SD) on the replicates. They are smaller than the symbol when not shown. (b) ${ }^{18} \mathrm{O}$ enrichment from irrigation water to leaf water $\left(\Delta^{\prime 18} \mathrm{O}_{\mathrm{LW}} \mathrm{IW}\right)$, from irrigation water to phytolith $\left(\Delta^{\prime 18} \mathrm{O}_{\text {Phyto-IW }}\right)$ and from leaf water to phytolith $\left(\Delta^{\prime 18} \mathrm{O}_{\mathrm{Phyto}-\mathrm{LW}}\right)$. (c) ${ }^{17} \mathrm{O}$-excess associated with the enrichment from irrigation water to leaf water $\left({ }^{17} \mathrm{O}-\mathrm{excess}_{\mathrm{e}} \mathrm{LW}-\mathrm{IW}\right)$, from irrigation water to phytolith $\left({ }^{17} \mathrm{O}\right.$-excess $\mathrm{e}$ Phyto-IW), and from leaf water to phytolith $\left({ }^{17} \mathrm{O}\right.$-excess $\mathrm{e}$ Phyto-LW). (d), (e) and (f) linear correlations for the $40-80 \%$ RH range extracted from (a), (b) and (c), respectively.

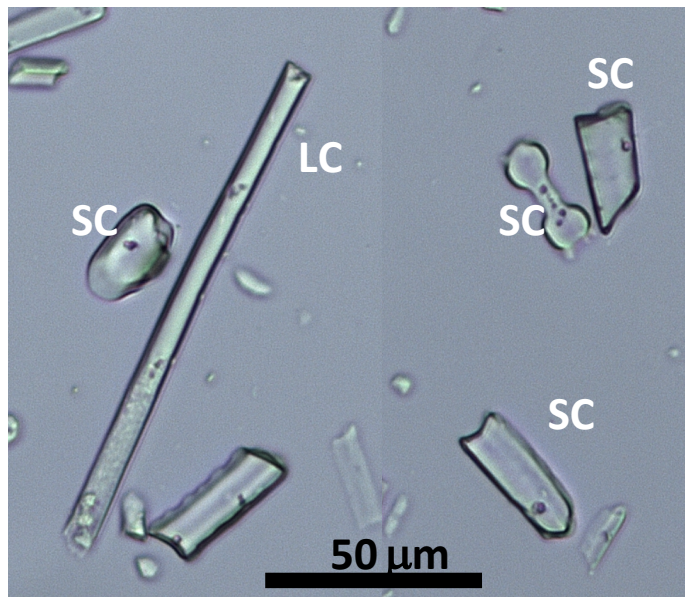

Figure 2. Growth chamber experiment: phytolith types extracted from Festuca arundinaceae and observed in natural light microscopy: epidermal long cell (LC), epidermal short cell (SC).

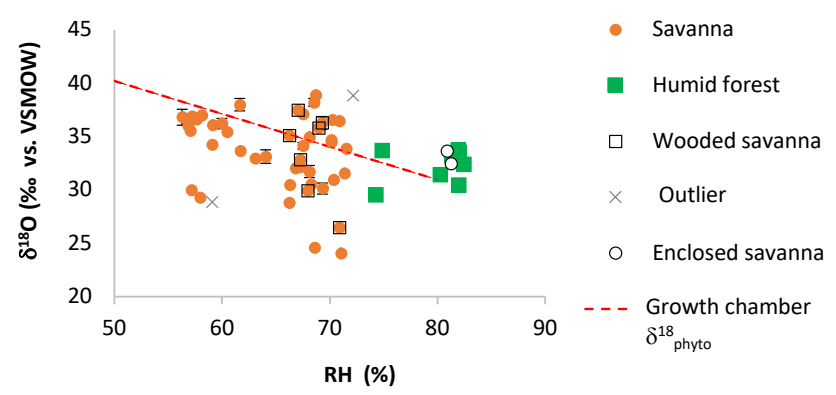

Figure 3. Natural West and Central African transect: $\delta^{\prime 18} \mathrm{O}$ of phytoliths $\left(\delta^{\prime 18} \mathrm{O}_{\text {Phyto }}\right)$ vs. relative humidity RH-rd0 $>1$ (see Fig. 4 for explanation). Error bars show standard deviation (SD) on the replicates. When not shown, they are smaller than the symbol.

$\Delta^{\prime 18} \mathrm{O}_{\mathrm{LW}-\mathrm{IW}}$ (Table 1), are due to the very high $\delta^{18} \mathrm{O}_{\mathrm{LW}}$ value of sample P3-100-10-05-16. However, as we do not have any explanation for this high value, these data were not excluded from further calculation. The ${ }^{17} \mathrm{O}$-excess values associated with the enrichment $\Delta^{\prime 18} \mathrm{O}_{\mathrm{LW}-\mathrm{IW}}$ (or ${ }^{17} \mathrm{O}$ - 

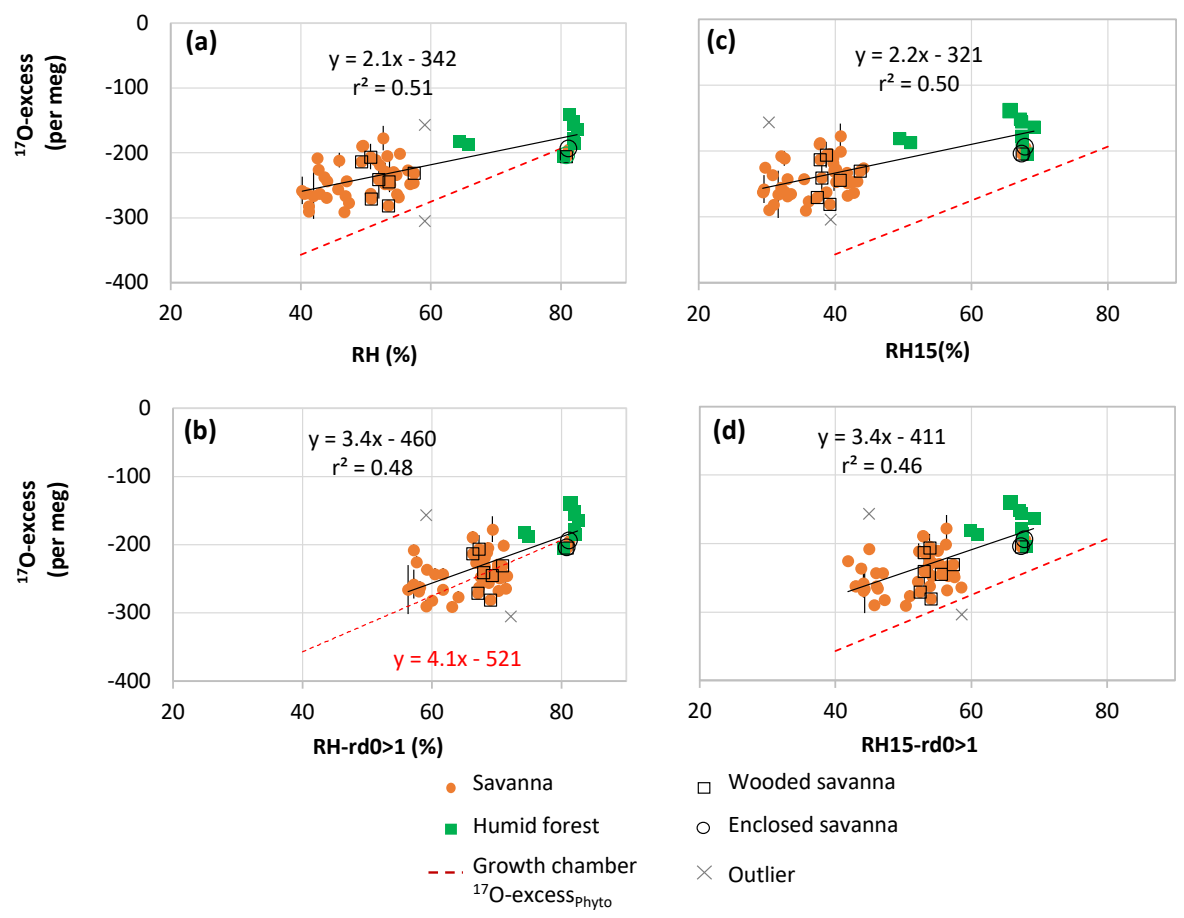

Figure 4. Natural West and Central African transect: ${ }^{17} \mathrm{O}$-excess vs. relative humidity (RH) of phytolith assemblages from soil tops collected under savanna, wooded savanna, humid forest and enclosed savanna along a humidity gradient (Table 1 ). The growth chamber ${ }^{17} \mathrm{O}-$ excess Phyto vs. RH correlation line is displayed for comparison. (a) RH-Av: yearly average of monthly means; (b) RH-rd0 > 1: yearly average of monthly means for months with at least 1 day with precipitation higher than $0.1 \mathrm{~mm}$; (c) RH15: RH at 15:00 UTC; (d) RH15-rd0 > 1: RH$\operatorname{rd0}>1$ at 15:00 UTC.

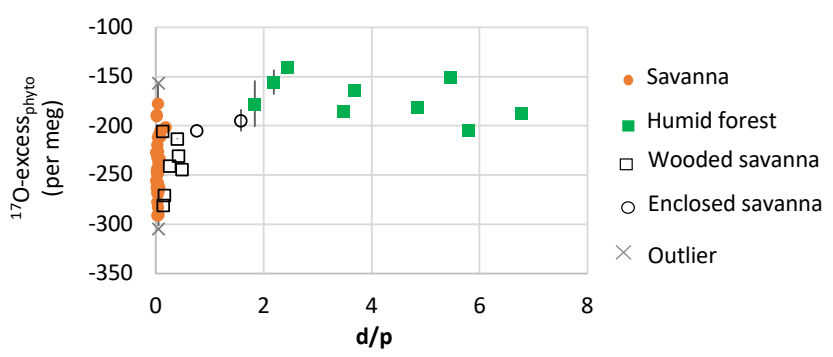

Figure 5. Natural West and Central African transect: ${ }^{17} \mathrm{O}$-excess of phytoliths $\left({ }^{17} \mathrm{O}\right.$-excess Phyto $)$ vs. $d / p$.

excess $\left._{\mathrm{e}} \mathrm{LW}-\mathrm{IW}=\Delta^{\prime 17} \mathrm{O}_{\mathrm{LW}-\mathrm{IW}}-0.528 \times \Delta^{\prime 18} \mathrm{O}_{\mathrm{LW}-\mathrm{IW}}\right)$ are scattered for a given $\mathrm{RH}$. The averaged value however follows a clear pattern (Fig. 1c; Table 1): it decreases slowly from 100 to $80 \% \mathrm{RH}$ (from $-88 \pm 48$ to $-75 \pm 20$ per meg,) and more rapidly from 80 to $40 \% \mathrm{RH}$ where it reaches $-159 \pm 9$ per meg. When the relationship is linearized, the slope of the line between ${ }^{17} \mathrm{O}$-excess $\mathrm{eW}$-IW and 40 to $80 \%$ $\mathrm{RH}$ is 2.3 per meg/\% (Fig. 1f). The raw values of $\lambda_{\mathrm{LW}-\mathrm{IW}}$ do not show any significant trend with $\mathrm{RH}$ and average $0.519 \pm 0.002$ (Table 1).

The average phytolith content ranges from 1.1 to $0.1 \%$ d.w. Silicification of the leaf blade of $F$. arundinacea in- creases with increasing transpiration and decreasing humidity (Table 1). Phytolith morphological identification shows that they formed preferentially in the epidermal short cell and to a smaller extent in the epidermal long cells (Fig. 2). The proportion of silicified long cells increases with increasing transpiration and decreasing RH (Table 1). Some hair and bulliform cells were also silicified, but in much smaller quantities. $\delta^{\prime 18} \mathrm{O}$ and ${ }^{17} \mathrm{O}$-excess of phytoliths $\left(\delta^{\prime 18} \mathrm{O}_{\text {Phyto }}\right.$ and ${ }^{17} \mathrm{O}$-excessphyto, respectively) show the same general trends with $\mathrm{RH}$ as $\delta^{18} \mathrm{O}_{\mathrm{LW}}$ and ${ }^{17} \mathrm{O}$-excess $\mathrm{LW}$ (Fig. 1a, Table S2).

The average value of the ${ }^{18} \mathrm{O}$-enrichment of phytoliths relative to the bulk leaf water $\left(\Delta^{\prime 18} \mathrm{O}_{\text {Phyto-LW }}\right)$ increases slowly (from $27.97 \pm 6.97$ to $28.47 \pm 0.38 \%$ ) when RH decreases from 100 to $80 \%$ and more rapidly from 80 to $40 \%$ where it reaches $32.32 \pm 1.92 \%$ (Fig. 1b, Table 1). With regard to the enrichment of phytoliths relative to the irrigation water, $\Delta^{\prime 18}$ Ophyto-IW shows the same trend with $\mathrm{RH}$ as $\Delta^{\prime 18} \mathrm{O}_{\mathrm{LW}-\mathrm{IW}}$ (Fig. 1b, Table 1 ). ${ }^{17} \mathrm{O}$-excess Phyto and ${ }^{17} \mathrm{O}-$

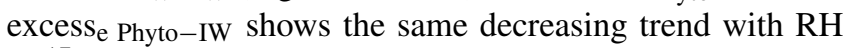
as ${ }^{17} \mathrm{O}$-excess $\mathrm{eW}-\mathrm{IW}$ (Fig. 1c, Table 1). When the relationships of ${ }^{17} \mathrm{O}$-excess Phyto and ${ }^{17} \mathrm{O}$-excess $\mathrm{e}_{\mathrm{e}}$ Phyto-IW with 40 to $80 \% \mathrm{RH}$ are linearized, the slopes of the lines are 4.1 and 4.3 per meg/\%, respectively (Fig. 1d, f). A Student's $t$ test (relevant when the variance of two data sets are equal; Andrade and Estévez-Pérez, 2014), calculated on the ${ }^{17} \mathrm{O}$ - 


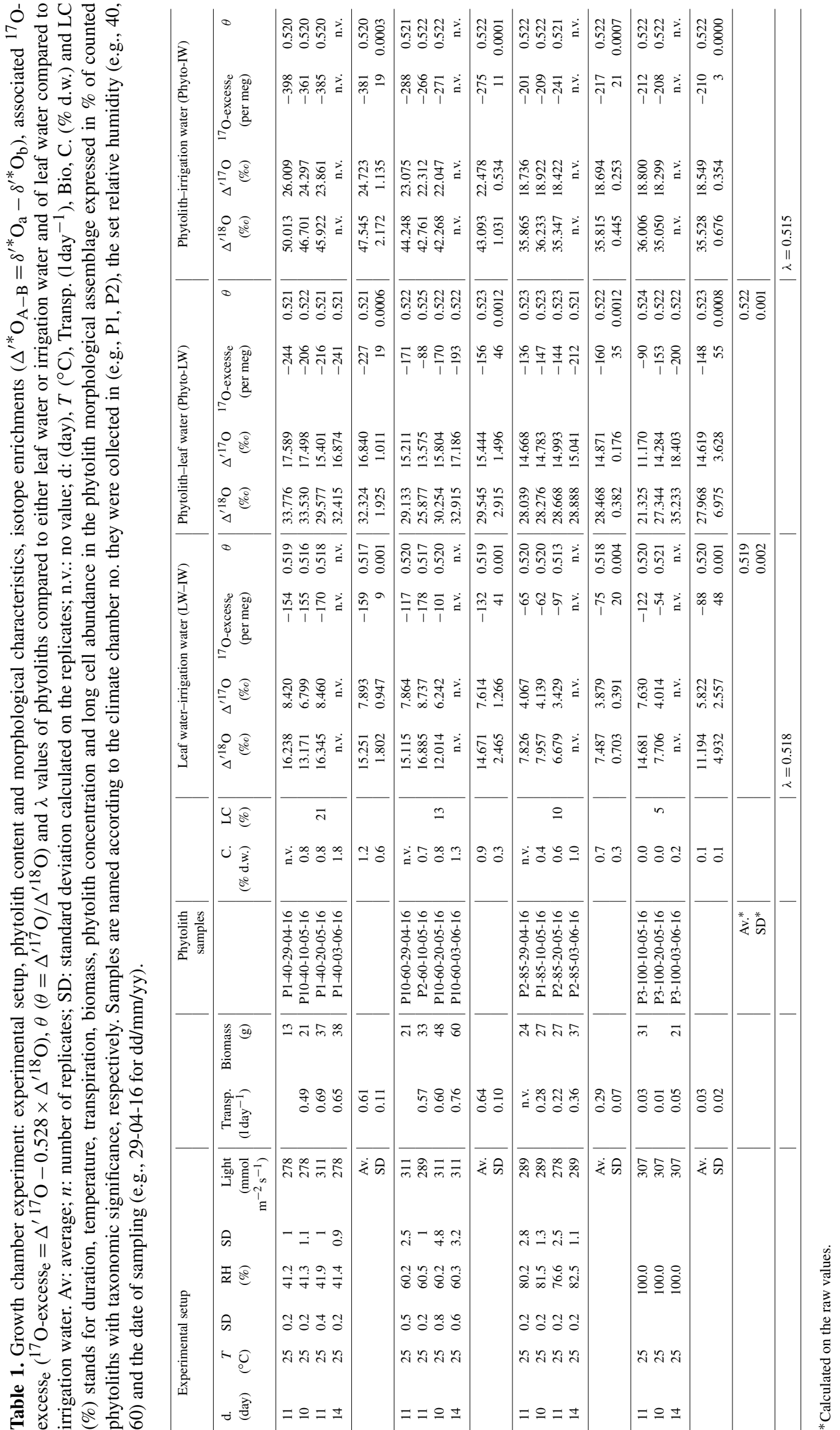


excess $\mathrm{e}_{\mathrm{LW}-\mathrm{IW}}$ vs. $\mathrm{RH}$ and ${ }^{17} \mathrm{O}$-excess $\mathrm{e}_{\mathrm{e}}$ Phyto-IW vs. $\mathrm{RH}$ data sets shows that the slopes of the lines are not statistically different for a $75 \%$ confidence interval. Thus, the link between ${ }^{17} \mathrm{O}$-excess $\mathrm{e}_{\mathrm{e}}$ Phyto-IW and RH is mainly due to the leaf water ${ }^{17} \mathrm{O}$-excess dependency on RH. The raw values of $\lambda$ Phyto-LW appears constant, averaging $0.522 \pm 0.001$ (Table 1).

\subsection{Natural samples}

Values of $\delta^{\prime 18} \mathrm{O}_{\text {Phyto }}$ and ${ }^{17} \mathrm{O}$-excess Phyto range, respectively, from 23.79 to $38.16 \%$ and from -140 to -290 per meg (Table 2). The variations are on the same order of magnitude as for the growth chamber experiment. The estimates of $\delta^{18} \mathrm{O}$ Pre vary little along the sampled transect (from -4.46 to $-3.22 \%$ ). No relationship is observed between $\delta^{\prime 18} \mathrm{O}_{\text {Phyto }}$ or the ${ }^{18} \mathrm{O}$ enrichment of phytoliths relative to precipitation $\left(\Delta^{\prime 18} \mathrm{O}_{\text {Phyto-Pre }}\right)$ and MAP, MAT or RH (Fig. 3, Table 2$)$.

Although scattered, the ${ }^{17} \mathrm{O}$-excess Phyto values show a significant positive linear correlation with RH (Fig. 4), regardless of which RH variable is taken into account. After excluding two outliers, the slopes of the correlation lines are 2.1 and 2.2 when RH and RH15 are taken into account, and 3.4 when either RH-rd0 $>1$ or RH15-rd0 $>1$ are considered. The relationship obtained between ${ }^{17} \mathrm{O}$-excessphyto and RH-rd0 $>1$ (i.e., $\mathrm{RH}$ of the wet months during which plants grow) is the closest to the one obtained between ${ }^{17} \mathrm{O}$-excess Phyto and $\mathrm{RH}$ in the growth chambers (Fig. 4b). It can be expressed as follows (Eq. 1):

$$
\begin{aligned}
{ }^{17} \text { O-excessPhyto } & =3.4 \times \text { RH-rd } 0>1 \\
& -460\left(r^{2}=0.48 ; p<0.001\right),
\end{aligned}
$$

where ${ }^{17} \mathrm{O}$-excess Phyto is expressed in per meg and $\mathrm{RH}$ in $\%$.

The excluded outliers (Table 3) are RIM1 and C3L4. RIM1 presents a very low ${ }^{17} \mathrm{O}$-excess $(-305$ per meg) relative to the ${ }^{17} \mathrm{O}$-excess of the samples with close $\mathrm{RH}-\mathrm{rd} 0>1$, i.e., from 71 to $74 \%$ (average of $-237 \pm 32$ per meg for 82 $78,83-116$ and 83-115). C3L4 is located next to C4L3 and under similar averaged $\mathrm{RH}$ but presents a ${ }^{17} \mathrm{O}$-excess higher by 133 per meg. RIM1 and C3L4 show morphological patterns very similar to the other assemblages with the same range of RH. Thus, the discrepancies may lie either in the fact that local RH variations may not be reflected in RH averaged estimates for $10^{\prime}\left(\approx 185 \mathrm{~km}^{2}\right)$ or in the particularity of the isotope composition of the local soil water (see discussion below).

The phytolith index $d / p$ ranges from 0.01 to 0.08 in savanna, from 0.14 to 0.49 in wooded savanna, from 0.76 to 1.58 in enclosed savanna and from 1.84 to 6.78 in humid forests (Table 2). This unambiguous increase in $d / p$ with tree cover density is in agreement with previous calibrations performed for the West African area (Bremond et al., 2005b). Interestingly, under high RH conditions, humid forest and enclosed savanna that are characterized by a large range of $d / p$ represent a small range of ${ }^{17} \mathrm{O}$-excess. Conversely, under lower RH conditions, savanna and wooded savanna that are characterized by a small range of $d / p$ represent a large range of ${ }^{17} \mathrm{O}$-excess (Fig. 5). This absence of a relationship between ${ }^{17} \mathrm{O}$-excess and tree cover density is also mirrored in Fig. 4, where phytolith samples from different vegetation types (i.e., savanna vs. wooded savanna or humid forests vs. enclosed savanna), that have developed under the same RH conditions, have the same range of ${ }^{17} \mathrm{O}$-excess.

\section{Discussion}

\subsection{Imprint of changes in atmospheric $\mathrm{RH}$ on the ${ }^{17} \mathrm{O}$-excess of leaf water}

In the bulk leaf water, the trends observed between $\Delta^{\prime 18} \mathrm{O}_{\mathrm{LW}-\mathrm{IW}}$ or ${ }^{17} \mathrm{O}$-excesse $\mathrm{LW}-\mathrm{IW}$ and $\mathrm{RH}$ are in agreement with an evaporative kinetic fractionation that increases when RH decreases, as expected from previous studies on the $\delta^{18} \mathrm{O}$ or ${ }^{17} \mathrm{O}$-excess evolution of leaf water (e.g., Cernusak et al., 2016; Landais et al., 2006; Li et al., 2017). The average value of $\lambda_{\mathrm{LW}-\mathrm{IW}}(0.519)$ is close to the value of $\theta_{\text {diff }}$ calculated for the diffusion of vapor in air (0.518; Barkan and Luz, 2007). As schematically described in Landais et al. (2016), $\lambda_{\text {transp }}$ (equivalent to $\lambda_{\mathrm{LW}-\mathrm{IW}}$ ) represents the interplay among three processes in the leaf boundary layer: (1) the equilibrium fractionation, which is only temperaturedependent (Majoube, 1971) and drives the isotope composition of leaf water along the equilibrium water line $\left(\theta_{\text {equil }}=\right.$ 0.529); (2) the diffusion transport leading to increasing kinetic fractionation with decreasing relative humidity along the diffusion line; (3) the isotope exchange of leaf water with atmospheric water vapor, decreasing from turbulent to laminar and molecular leaf boundary layer vapor transport conditions (e.g., Buhay et al., 1996). In the case of the growth chamber experiment, the fact that $\lambda_{\mathrm{LW}-\mathrm{IW}}$ is close to $\theta_{\text {diff }}$ supports that the increasing diffusion of vapor in air when $\mathrm{RH}$ decreases or transpiration increases is the main process controlling the evolution of ${ }^{17} \mathrm{O}$-excess $\mathrm{LW}_{\mathrm{LW}}$. At high humidity $(80-100 \% \mathrm{RH})$, the kinetic fractionation likely reaches its minimum as the diffusion process becomes limited.

The $\delta^{18} \mathrm{O}_{\mathrm{LW}}$ is commonly modelled as a function of the isotope composition of absorbed water, the isotope composition of water vapor, and RH (Craig and Gordon, 1965). The Craig and Gordon simple approach overestimates $\delta^{18} \mathrm{O} \mathrm{LW}$ and different corrections have been proposed to take into account the diffusion of the evaporating water back to the leaf lamina and the advection of less evaporated stem water (i.e., the Péclet effect, Buhay et al., 1996; Helliker and Ehleringer, 2000; Roden et al., 2000; Farquhar and Gan, 2003; Farquhar and Cernusak, 2005; Ripullone et al., 2008; Treydte et al., 2014). In the growth chamber experiment, where water availability, relative humidity, and temperature were kept constant, we assume that transpiration rapidly reached a steady state and that the isotope composition of transpired water was the same as that of the irrigation water entering 


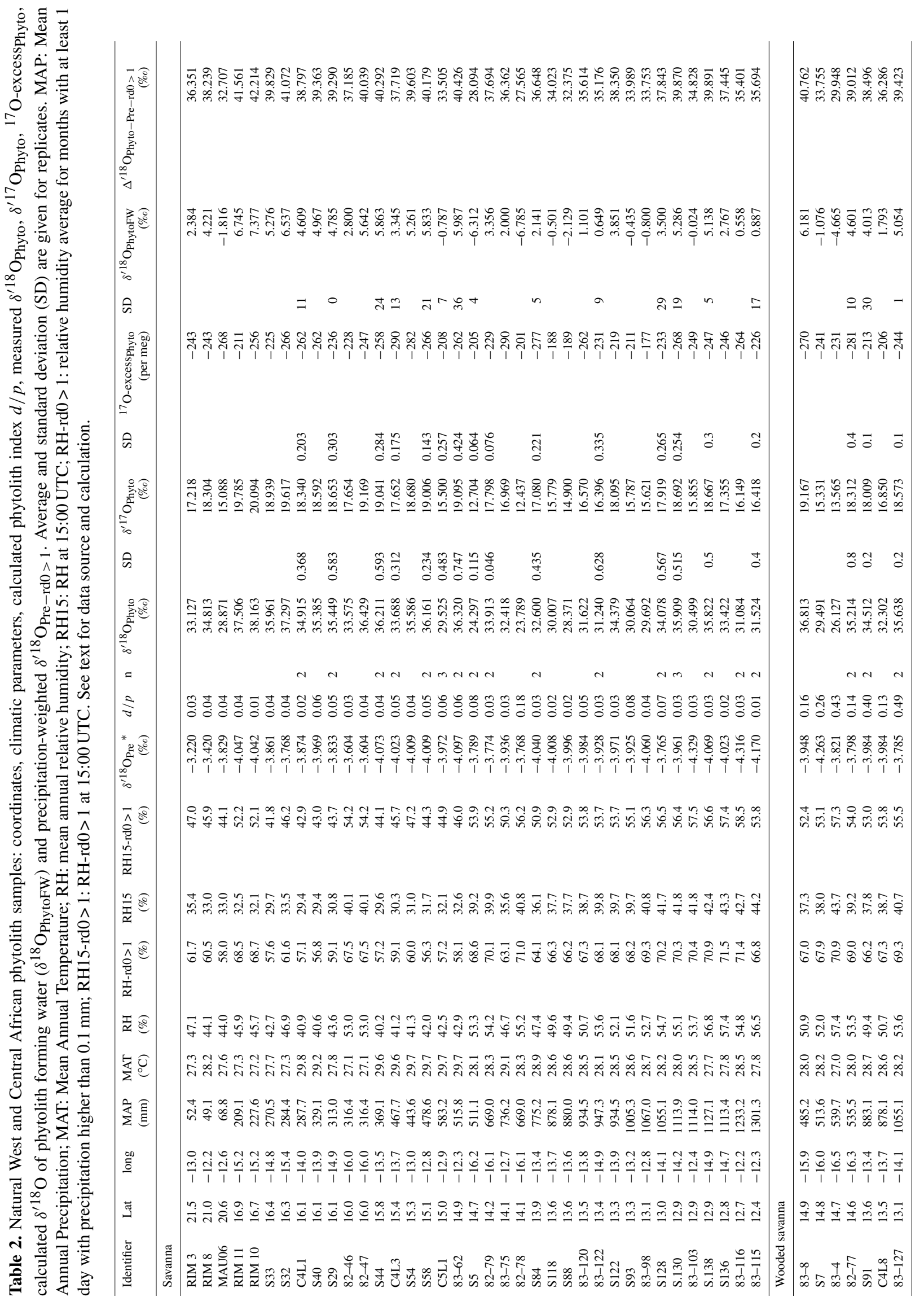




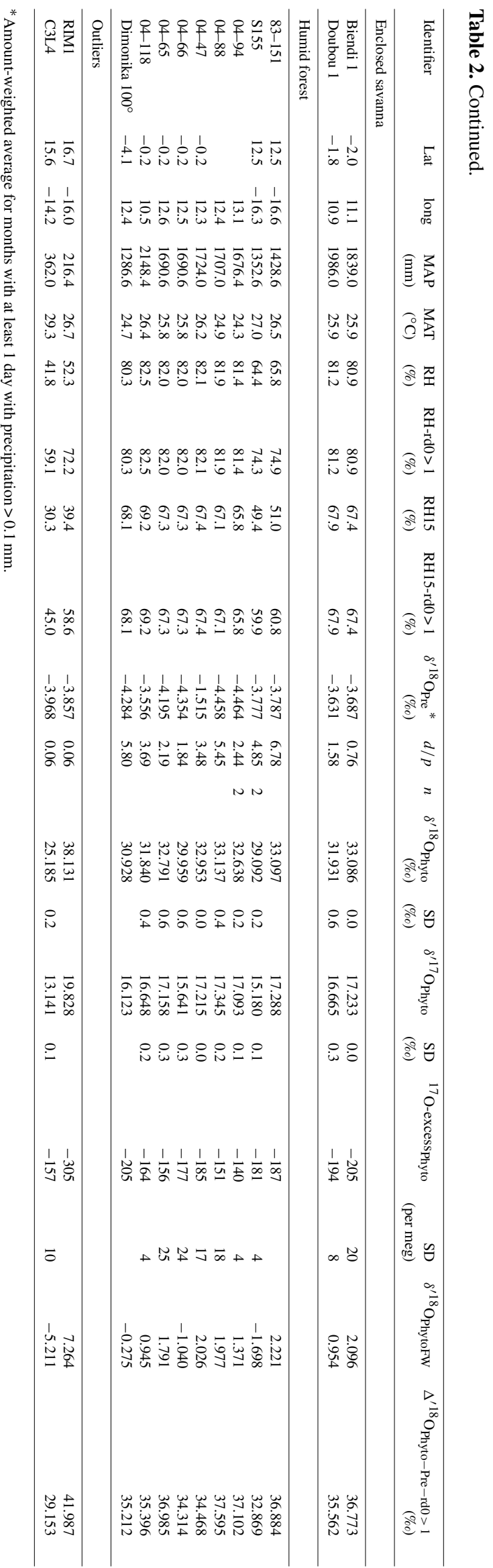

the plant (e.g., Welp et al., 2008). A tentative estimate of the theoretical value of $\Delta^{\prime 18} \mathrm{O}_{\mathrm{LW}-\mathrm{IW}}, \Delta^{\prime 17} \mathrm{O}_{\mathrm{LW}-\mathrm{IW}}$ and ${ }^{17} \mathrm{O}$ excess $\mathrm{e}_{\mathrm{LW}} \mathrm{IW}$ was performed using the equations proposed for ${ }^{18} \mathrm{O}$-enrichment by Cernusak et al. (2016) (Table S3). For calculating the $\Delta{ }^{17} \mathrm{LW}$-IW we used for the equilibrium and kinetic fractionations (respectively ${ }^{17} \alpha_{\text {eq }}$ and ${ }^{17} \alpha_{k}$ in Table S3) ${ }^{17} \alpha_{\text {eq }}={ }^{18} \alpha_{\text {eq }}^{0.529}$ and ${ }^{17} \alpha_{k}={ }^{18} \alpha_{k}^{0.518}$. As expected, the predicted $\Delta^{\prime 18} \mathrm{O}_{\mathrm{LW}}$-IW values were all higher than the observed values by several \%o. Helliker and Ehleringer (2000) proposed, for monocotyledonous species characterized by a vertical parallel veinal structure, to use instead of the Craig and Gordon model the Gat and Bowser (1991) equation describing the movement of water through a sequence of pools in series. However, this model would further increase the estimates of $\Delta^{\prime 18} \mathrm{O}_{\mathrm{LW}}$-IW. The predicted ${ }^{17} \mathrm{O}$-excess displayed in Table S3 was either higher or lower than the observed ${ }^{17} \mathrm{O}$-excess $\mathrm{e}_{\mathrm{LW}}$-IW. Predicted $\lambda_{\mathrm{LW}-\mathrm{IW}}$ increased with RH from 0.521 to 0.529 which is far from the observed values averaging 0.519 . The predicted value of 0.529 at $100 \% \mathrm{RH}$ reflects pure equilibrium in a situation where irrigation water and water vapor are assumed to have similar isotope composition since irrigation water is directly vaporized into the chamber (Table S3), without any fractionation. Sensitivity tests show that regardless of the model chosen (Buhay et al., 1996; Cernusak et al., 2016; Li et al., 2017), estimations of $\lambda_{\mathrm{LW}-\mathrm{IW}}$ are very dependent on the isotope compositions of the water vapor ( $\mathrm{Li}$ et al., 2017), not measured either in our experiment or in previous studies (Landais et al., 2006; Li et al., 2017). In the natural environment, a first-order approximation for the isotope composition of water vapor is to consider equilibrium with precipitation. As a result of water-vapor equilibrium fractionation and soil water ${ }^{18} \mathrm{O}$-enrichment, this can lead to a water vapor ${ }^{18} \mathrm{O}$ depleted by 10-13\%o compared to the soil water (Landais et al., 2006; Lehmann et al., 2018). In this case the predicted $\lambda_{\text {transp }}$ (equivalent to $\lambda_{\mathrm{LW}-\mathrm{SW}}$ ) decreases with increasing humidity. Finally, because wrong values of the isotope compositions of the water vapor may affect significantly the calculation of $\Delta^{\prime 18} \mathrm{O}_{\mathrm{LW}-\mathrm{IW}}, \Delta^{\prime 17} \mathrm{O}$-excess $\mathrm{e}_{\mathrm{LW}-\mathrm{IW}}$ and $\lambda_{\mathrm{LW}-\mathrm{SW}}$, we call for vapor isotope measurements as a prerequisite to accurately model the leaf water triple oxygen isotope evolution with RH. However, overall, despite the uncertainties on the predicted evolution of $\lambda_{\mathrm{LW}}$-SW with $\mathrm{RH}$, the predicted value of ${ }^{17} \mathrm{O}$-excess $e_{\mathrm{eW}} \mathrm{LW}$ decreases when $\mathrm{RH}$ increases, which is also observed, as well as reflected in the triple isotope composition of phytoliths, as discussed below.

\subsection{Imprint of changes in atmospheric $\mathrm{RH}$ on the ${ }^{17} \mathrm{O}$-excess of phytoliths}

Polymerization of silica is supposed to occur in isotope equilibrium with the forming water, and, therefore, to be only governed by temperature and the isotope composition of the forming water. Almost a dozen temperature-dependent relationships have been empirically 
established between the $\delta^{18} \mathrm{O}$ of quartz, sinters, cherts, diatoms or phytoliths and the $\delta^{18} \mathrm{O}$ of their forming water $\left(\delta^{18} \mathrm{O}_{\mathrm{PhytoFW}}\right)$. Although the obtained fractionation coefficients are close (from -0.2 to $-0.4 \% 0^{\circ} \mathrm{C}^{-1}$ ), the range of fractionation $\left(\Delta^{18} \mathrm{O}_{\text {Phyto-PhytoFW }}\right)$ is large (see synthesis in Alexandre et al., 2012). The $\Delta^{18} \mathrm{O}_{\text {Phyto-PhytoFW val- }}$ ues obtained in the frame of the growth chamber experiment (ranging from $27.9 \pm 7.2$ to $32.3 \pm 2.2 \%$ ) encompass the $\Delta^{18}$ OPhyto-PhytoFW of $31.1 \%$ calculated from the Dodd and Sharp (2010) relationship for $25^{\circ} \mathrm{C}$. It is lower than the values of 36.4 and $36 \%$ at $25^{\circ} \mathrm{C}$, calculated from Sharp et al. (2016) and Alexandre et al. (2012). Whereas Alexandre et al. (2012) and Sharp et al. (2016) generally estimated the forming-water $\delta^{18} \mathrm{O}$ values, Dodd and Sharp (2010) measured the the $\delta^{18} \mathrm{O}$ values of the water samples. The proximity of the obtained range of $\Delta^{18} \mathrm{O}_{\text {Phyto-LW values to the }}$ $\Delta^{18}$ OPhyto-PhytoFw calculated from Dodd and Sharp (2010) suggests that phytoliths formed in equilibrium with a water of isotope composition close to that of the bulk leaf water. This is additionally supported by the obtained averaged value of $\lambda_{\text {Phyto-LW }}(0.522 \pm 0.001)$ close to the $\theta_{\mathrm{SiO}_{2}}$-water equilibrium value of 0.524 calculated for $25^{\circ} \mathrm{C}$ from Sharp et al. (2016).

Evolution of the triple isotope composition of bulk leaf water and phytoliths can be illustrated by plotting $\delta^{\prime 17} \mathrm{O}$ vs. $\delta^{\prime 18} \mathrm{O}$, or ${ }^{17} \mathrm{O}$-excess vs. $\delta^{\prime 18} \mathrm{O}$ (Fig. 6) which is more appropriate to evidence small variations. Figure 6 shows that the leaf water evolved from the irrigation water pool, becomes increasingly subject to kinetic fractionation when RH decreased. This evolution follows a single leaf water line reflecting $\lambda_{\mathrm{LW}-\mathrm{IW}}=0.519$ (Table 1 ). Then, if phytoliths polymerized from the bulk leaf waters, at $25^{\circ} \mathrm{C}$, according to a constant equilibrium fractionation, their expected isotope signature should follow a line parallel to the leaf water line. This is the case for phytoliths formed at RH higher than $40 \%$. However, the isotope signature of phytoliths formed at $40 \%$ RH suggests a forming water more evaporated than the bulk leaf water. The Péclet effect, which is known to scale with transpiration (e.g., Barnard et al., 2007), can explain this discrepancy. Advection of less evaporated stem water may decrease $\delta^{\prime 18} \mathrm{O}_{\mathrm{LW}}$ and increase ${ }^{17} \mathrm{O}$-excess $\mathrm{LW}_{\mathrm{LW}}$ relative to $\delta^{\prime 18} \mathrm{O}$ and ${ }^{17} \mathrm{O}$-excess of the epidermal water prone to evaporation and from which phytoliths formed. At this point, the data scattering prevents further discussion but the possibility that when RH is low, or when transpiration is high, the phytolith forming-water is different from the bulk leaf water must be investigated in future research developments.

With regard to the natural samples, whereas no relationship was found between $\delta^{\prime 18} \mathrm{O}_{\text {Phyto }}$ and $\mathrm{RH}$, a clear positive linear dependency of ${ }^{17} \mathrm{O}$-excessphyto on $\mathrm{RH}$ was shown, equivalent to 2.1 per meg/\% when the annual $\mathrm{RH}$ average was taken into account, or to 3.4 per meg/\% when the average of the growing season (RH-rd0 $>1$ ) was taken into account (Fig. 4). These coefficients are close to the slope of the lines obtained for the growth chamber experi- ment between ${ }^{17} \mathrm{O}$-excess Phyto,${ }^{17} \mathrm{O}$-excess $\mathrm{e}$ LW-Iw and ${ }^{17} \mathrm{O}$ excesse Phyto-IW and 80 to $40 \%$ RH (Fig. 1a, e and f). This consistency represents a major positive step in examining whether changes in atmospheric RH imprint the ${ }^{17} \mathrm{O}$-excess of natural phytolith assemblages in a predictable way. Without taking into account the two outliers, the linear regression between RH-rd0 $>1$ and ${ }^{17} \mathrm{O}$-excessphyto for a $95 \%$ confidence interval can be expressed as follows:

$$
\begin{aligned}
\text { RH-rd0 }>1 & =0.14 \pm 0.02 \text { (S.E.) } \times{ }^{17} \text { O-excess } \\
& +100.5 \pm 4.7 \text { (S.E.) }
\end{aligned}
$$

where ${ }^{17} \mathrm{O}$-excess Phyto is expressed in per meg and $\mathrm{RH}$ in $\%, r^{2}=0.48$, and $p<0.001$. S.E. stands for standard error. The S.E. of the predicted RH-rd0 $>1$ value is $\pm 5.6 \%$. However, the data scattering (Fig. 4) calls for assessing additional parameters that can contribute to changes in ${ }^{17} \mathrm{O}$-excess Phyto, besides $\mathrm{RH}$, before using the ${ }^{17} \mathrm{O}$-excess Phyto for quantitative $\mathrm{RH}$ reconstruction.

One can expect that the isotope composition of the soil water taken up by the roots will impact ${ }^{17} \mathrm{O}$-excessPhyto. In tropical dry and humid areas, evaporative kinetic fractionation can lead to a ${ }^{18} \mathrm{O}$-enrichment of the soil water of several \%o, in the first dm depth (e.g., Gaj et al., 2016; Liu et al., 2010). Spatial variability in the composition of the rainfall feeding the upper soil water may also intervene. However, the amount-weighted values of $\delta^{\prime 18} \mathrm{OPre}_{\mathrm{Pre}}$ along the sampled transect vary little (Table 2). With regard to ${ }^{17} \mathrm{O}$-excess, changes in soil water evaporation rather than the small variations expected for ${ }^{17} \mathrm{O}$-excess Pre (Landais et al., 2010b; Li et al., 2015) should impact the evolution of ${ }^{17} \mathrm{O}$-excessphyto, although, here, the lack of measurements only allows for speculation.

The vegetation type and the plant part from which phytoliths come from may also bring some noise to the relationship between ${ }^{17} \mathrm{O}$-excess ${ }_{\text {phyto }}$ and $\mathrm{RH}$. In grasses, leaf water is expected to be more prone to evaporative enrichment than stem water, and inside the leaf itself, the heterogeneity of evaporative sites repartition and water movements can lead to a significant heterogeneity in the $\delta^{18} \mathrm{O}$ signatures of water and phytoliths (Cernusak et al., 2016; Helliker and Ehleringer, 2000; Webb and Longstaffe, 2002). However, soil top phytolith assemblages likely record several decades of annual bulk phytolith production and their isotope composition is expected to be an average. This would explain the consistency of the ${ }^{17} \mathrm{O}$-excessphyto data obtained from bulk grass phytoliths from climate chambers and the bulk phytolith assemblages from natural vegetation. Further investigation on the extent of the heterogeneity of ${ }^{17} \mathrm{O}$-excess in water and phytoliths in mature grasses would help to verify this assumption. In trees, the Globular granulate phytolith is assumed to come from the non-transpiring secondary xylem of the wood. Thus Globular granulate phytoliths should present an isotope signature closer to that of the soil water, or less impacted by kinetic fractionation than grass phytoliths. How- 


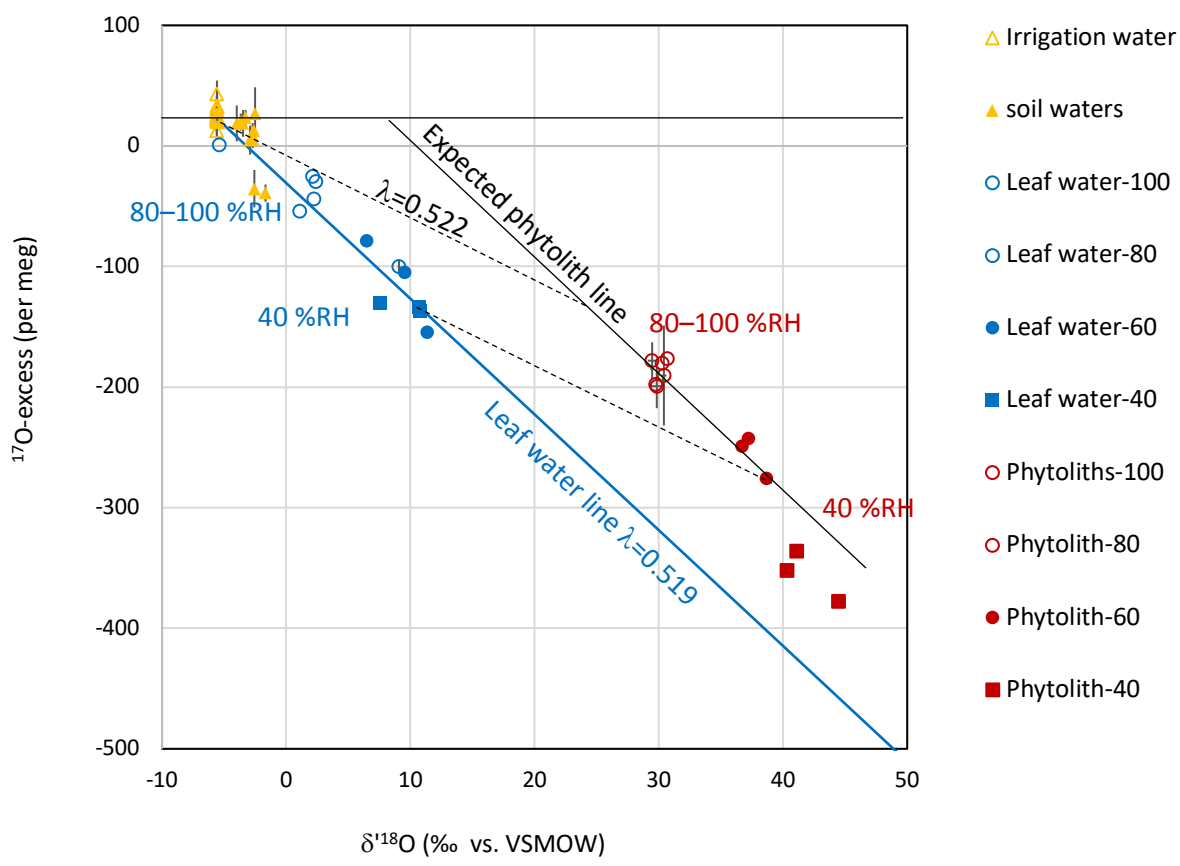

Figure 6. Growth chamber experiment: ${ }^{17} \mathrm{O}$-excess vs. $\delta^{\prime 18} \mathrm{O}$ of irrigation water (IW), soil water (SW), bulk leaf water (LW) and phytolith (Phyto). Error bars show standard deviation (SD) on the replicates. The leaf water line (blue) represents how the triple oxygen isotope composition of the bulk leaf water of Festuca arundinacea evolves from an irrigation water signature to a more evaporated water signature when RH decreases. Assuming that phytoliths precipitate from the bulk leaf water, the expected phytolith line (black) should be parallel to the leaf water line as the equilibrium fractionation between phytolith and leaf water is constant at constant temperature $\left(25^{\circ} \mathrm{C}\right)$. In the investigated case this fractionation, represented by the black dotted line, is equivalent to $\lambda=0.522$ (Table 1). The isotope signature of phytoliths formed at RH higher than $40 \%$ follow the expected phytolith line. However, the isotope signature of phytoliths formed at $40 \%$ RH suggest a forming water more evaporated than the bulk leaf water.

ever, for a given range of RH, samples with significant representations of both phytolith categories (i.e., wooded savanna and enclosed savanna samples with $d / p$ from 0.1 to 1.6 ) present ${ }^{17} \mathrm{O}$-excess values close to the values obtained by samples with very low or very high $d / p$ (Figs. 4 and 5). To further assess the significance of the Globular granulate isotope signature, we calculated $\delta^{\prime 18} \mathrm{O}_{\mathrm{PhytoFW}}$ values (Table 2) using the Dodd and Sharp (2010) fractionation factor and compared it to the precipitation-weighted $\delta^{\prime 18} \mathrm{O}$ Pre-rd0 $>1$ average. For the humid forest assemblages, $\delta^{\prime 18} \mathrm{O}_{\text {PhytoFW val- }}$ ues are higher than $\delta^{\prime 18} \mathrm{O}_{\mathrm{Pre}-\mathrm{rd} 0>1}$ by $4.6 \pm 1.5 \%$. This difference is larger than the range of ${ }^{18} \mathrm{O}$-enrichment observed for the upper $10 \mathrm{~cm}$ depth of soil water under tropical humid forests (2-3\%o; Liu et al., 2008; Stahl et al., 2013), suggesting that evaporative isotope signatures of both soils and leaf water imprinted the Globular granulate phytolith type. This is in line with recent ${ }^{18} \mathrm{O}$-labelling experiment showing that the ${ }^{18} \mathrm{O}$-enriched oak phloem water may exchange with xylem water under low transpiration rates (Lehmann et al., 2018). Complementary examination of the isotope signature of phytolith assemblages from forests growing under different $\mathrm{RH}$ conditions (i.e., dry forests, humid forests, rainforests), as well as further investigation of the anatomical origin of the Globular granulate phytolith type, are now required to fur- ther discuss the meaning of the ${ }^{17} \mathrm{O}$-excess signal brought by wooded savanna and tropical forest phytolith assemblages.

Biases due to the calibration methodology may also be responsible for the data scattering. Imperfect adequacy between the space scales recorded by the soil top phytolith assemblages and the RH variables may come into play. Phytolith assemblages represent a mixture of local and windtransported phytoliths. In the open Saharan, Sahelian and Sudanian zones of West Africa the winter low-altitude northeasterly trade winds may transport phytoliths southward, reducing differences between assemblages from different biogeographic zones and increasing differences among assemblages of a given biogeographic zone (Bremond et al., 2005b). Additional samples from other geographic zones are thus needed to increase the robustness of the relationship. With regard to the recorded timescales, the CRU RH 30-year averages are in agreement with the several decades of phytolith production.

\section{Conclusions}

The present combination of growth chamber and in situ transect calibrations lay the groundwork for further examination 
of the robustness of the ${ }^{17} \mathrm{O}$-excessphyto as a proxy of changes in RH. The growth chamber experiment demonstrated that change in RH imprints ${ }^{17} \mathrm{O}$-excessphyto (by 4.1 per meg/\% between 40 and $80 \% \mathrm{RH}$ ) or the ${ }^{17} \mathrm{O}$-excesse Phyto-IW (by 4.3 per meg/\%, between 40 and $80 \% \mathrm{RH}$ ) through its imprint on ${ }^{17} \mathrm{O}$-excess $\mathrm{e}_{\mathrm{LW}-\mathrm{IW}}$. As the isotope composition of the irrigation water was stable, and transpiration likely reached a steady state, the positive correlation between ${ }^{17} \mathrm{O}$-excess $s_{\mathrm{LW}}$ and RH was only governed by the kinetic fractionation occurring in the leaf epidermis water subject to evaporation, as supported by the averaged value of $\lambda_{\mathrm{LW}-\mathrm{IW}}$ of 0.519 , close to $\theta_{\text {diff. }}$.

In order to model the triple oxygen isotope fractionation in play at the soil/plant/atmosphere interface we require direct and continuous measurements of the triple isotope composition of water vapor. Such measurements should develop in the near future through the use of isotope ratio infrared analyzers (e.g., Berkelhammer et al., 2013; Schmidt et al., 2010). We also suggest to constrain as much as possible the isotope composition of the soil water taken up by the roots. Stem water is usually used as an analogue of soil water when modelling $\delta^{\prime 17} \mathrm{O}_{\mathrm{LW}}$ and $\delta^{\prime 18} \mathrm{O}_{\mathrm{LW}}$ (Landais et al., 2006; Li et al., 2017). However, in the stem, water in the phloem that is bidirectional (moves up and down the plant's stem) receives the contribution of evaporating leaf water, and water in the xylem that is unidirectional (moves up the plant's stem) may exchange with phloem waters (Lehmann et al., 2018). Consequently one may expect the isotope composition of stem water to be slightly different than that of soil water (Berkelhammer et al., 2013; Treydte et al., 2014).

When plotting ${ }^{17} \mathrm{O}$-excess Phyto vs. $\mathrm{RH}$, the samples collected along the West and Central African relative humidity transect define a correlation coefficient ranging from 2.1 to 3.4 per meg/\% (depending on the RH variable taken into account) and lay close to the growth chamber ${ }^{17} \mathrm{O}$-excess Phyto line. This supports that RH is an important control of ${ }^{17} \mathrm{O}$ excess Phyto in natural environment, even if phytolith assemblages come from different vegetation types. However, other parameters such as changes in the triple isotope composition of the soil water, vegetation source or imperfect adequation between the space scales recorded by the soil top phytolith assemblages and the RH variables may come into play and explain the scattering of ${ }^{17} \mathrm{O}$-excess Phyto. Assessment of these parameters through additional growth chambers experiments and field campaigns will bring us closer to an accurate proxy of changes in relative humidity.

Data availability. The underlying research data are available in the Supplement.

Supplement. The supplement related to this article is available online at: https://doi.org/10.5194/bg-15-3223-2018-supplement.
Competing interests. The authors declare that they have no conflict of interest.

Acknowledgements. This study was supported by the French program INSU-LEFE and benefited from the CNRS human and technical resources allocated to the ECOTRONS Research Infrastructures as well as from the state allocation "Investissements d'Avenir" ANR-11-INBS-0001.

Edited by: Aldo Shemesh

Reviewed by: two anonymous referees

\section{References}

Affolter, S., Häuselmann, A. D., Fleitmann, D., Häuselmann, P., and Leuenberger, M.: Triple isotope $\left(\delta \mathrm{D}, \delta^{17} \mathrm{O}, \delta^{18} \mathrm{O}\right)$ study on precipitation, drip water and speleothem fluid inclusions for a Western Central European cave (NW Switzerland), Quat. Sci. Rev., 127, 73-89, 2015.

Aleman, J., Leys, B., Apema, R., Bentaleb, I., Dubois, M. A., Lamba, B., Lebamba, J., Martin, C., Ngomanda, A., Truc, L., et al.: Reconstructing savanna tree cover from pollen, phytoliths and stable carbon isotopes, J. Veg. Sci., 23, 187-197, 2012.

Alexandre, A. and Brémond, L.: Comment on the paper in Quaternary International: "Methodological concerns for analysis of phytolith assemblages: Does count size matter?" (C.A.E. Strömberg), Quat. Int., 193, 141-142, 2009.

Alexandre, A., Meunier, J.-D., Colin, F., and Koud, J.-M.: Plant impact on the biogeochemical cycle of silicon and related weathering processes, Geochim. Cosmochim. Acta, 61, 677-682, 1997.

Alexandre, A., Crespin, J., Sylvestre, F., Sonzogni, C., and Hilbert, D. W.: The oxygen isotopic composition of phytolith assemblages from tropical rainforest soil tops (Queensland, Australia): validation of a new paleoenvironmental tool, Clim. Past, 8, 307324, https://doi.org/10.5194/cp-8-307-2012, 2012.

Alexandre, A., Balesdent, J., Cazevieille, P., Chevassus-Rosset, C., Signoret, P., Mazur, J.-C., Harutyunyan, A., Doelsch, E., Basile-Doelsch, I., Miche, H., and Santos, G. M.: Direct uptake of organically derived carbon by grass roots and allocation in leaves and phytoliths: ${ }^{13} \mathrm{C}$ labeling evidence, Biogeosciences, 13, 1693-1703, https://doi.org/10.5194/bg-13-1693-2016, 2016.

Andrade, J. M. and Estévez-Pérez, M. G.: Statistical comparison of the slopes of two regression lines: A tutorial, Anal. Chim. Acta, 838, 1-12, 2014.

Angert, A., Cappa, C. D., and DePaolo, D. J.: Kinetic O-17 effects in the hydrologic cycle: Indirect evidence and implications, Geochim. Cosmochim. Acta, 68, 3487-3495, 2004.

Backwell, L. R., McCarthy, T. S., Wadley, L., Henderson, Z., Steininger, C. M., deKlerk B., Barré, M., Lamothe, M., Chase, B. M., Woodborne, S., Susino, J. G., Bamford, M., Sievers, C., Brinks, J., Rossouw, L., Pollarolo, L., Trower, G., Scott, L., and d'Errico, F.: Multiproxy record of late Quaternary climate change and Middle Stone Age human occupation at Wonderkrater, South Africa, Quat. Sci. Rev., 99, 42-59, 2014.

Barkan, E. and Luz, B.: High precision measurements of ${ }^{17} \mathrm{O} /{ }^{16} \mathrm{O}$ and ${ }^{18} \mathrm{O} /{ }^{16} \mathrm{O}$ ratios in $\mathrm{H}_{2} \mathrm{O}$, Rapid Commun. Mass Spectrom., 19, 3737-3742, 2005. 
Barkan, E. and Luz, B.: Diffusivity fractionations of $\mathrm{H}_{2}(16) \mathrm{O} / \mathrm{H}_{2}(17) \mathrm{O}$ and $\mathrm{H}_{2}(16) \mathrm{O} / \mathrm{H}_{2}(18) \mathrm{O}$ in air and their implications for isotope hydrology, Rapid Commun. Mass Spectrom. RCM, 21, 2999-3005, 2007.

Barnard, R. L., Salmon, Y., Kodama, N., Sörgel, K., Holst, J., Rennenberg, H., Gessler, A., and Buchmann, N.: Evaporative enrichment and time lags between delta ${ }^{18} \mathrm{O}$ of leaf water and organic pools in a pine stand, Plant Cell Environ., 30, 539-550, 2007.

Bartlein, P. J., Harrison, S. P., Brewer, S., Connor, S., Davis, B. S., Gajewski, K., Guiot, J., Harrison-Prentice, T. I., Henderson, A., Peyron, O., Prentice, I. C., Scholze, M., Seppä, H., Shuman, B., Sugita, S., Thompson, R. S., Viau, A. E., Williams, J., and Wu, H.: Pollen-based continental climate reconstructions at 6 and 21 ka: a global synthesis, Clim. Dyn., 37, 775-802, 2010.

Berkelhammer, M., Hu, J., Bailey, A., Noone, D. C., Still, C. J., Barnard, H., Gochis, D., Hsiao, G. S., Rahn, T., and Turnipseed, A.: The nocturnal water cycle in an open-canopy forest, J. Geophys. Res.-Atmos., 118, 10225-10242, 2013.

Bony, S., Colman, R., Kattsov, V. M., Allan, R. P., Bretherton, C. S., Dufresne, J. L., Hall, A., Hallegatte, S., Holland, M. M., Ingram, W., Randall, D. A., Soden, B. J., Tselioudis, G., and Webb, M.: How well do we understand and evaluate climate change feedback processes?, J. Clim., 19, 3445-3482, 2006.

Bowen, G. J. and Revenaugh, J.: Interpolating the isotopic composition of modern meteoric precipitation, Water Resour. Res., 39, 1299, https://doi.org/10.1029/2003WR002086, 2003.

Bowen, G. J. and Wilkinson, B.: Spatial distribution of $\delta^{18} \mathrm{O}$ in meteoric precipitation, Geology, 30, 315-318, 2002.

Bowen, G. J., Wassenaar, L. I., and Hobson, K. A.: Global application of stable hydrogen and oxygen isotopes to wildlife forensics, Oecologia, 143, 337-348, 2005.

Bowling, D. R., Schulze, E. S., and Hall, S. J.: Revisiting streamside trees that do not use stream water: can the two water worlds hypothesis and snowpack isotopic effects explain a missing water source?, Ecohydrology, 10, n/a-n/a, 2017.

Bremond, L., Alexandre, A., Hely, C., and Guiot, J.: A phytolith index as a proxy of tree cover density in tropical areas: Calibration with Leaf Area Index along a forest-savanna transect in southeastern Cameroon, Glob. Planet. Change, 45, 277-293, 2005 a.

Bremond, L., Alexandre, A., Peyron, O., and Guiot, J.: Grass water stress estimated from phytoliths in West Africa, J. Biogeogr., 32, 311-327, 2005b.

Buhay, W. M., Edwards, T. W. D., and Aravena, R.: Evaluating kinetic fractionation factors used for reconstructions from oxgen and hydrogen isotope ratios in plant water and cellulose, Geochim. Cosmochim. Acta, 60, 2209-2218, 1996.

Cernusak, L. A., Barbour, M. M., Arndt, S. K., Cheesman, A. W., English, N. B., Feild, T. S., Helliker, B. R., Holloway-Phillips, M. M., Holtum, J. A. M., Kahmen, A., McInernez, F. A., Munksgaard, N. C., Simonin, K. A., Song, X., Stuart-Williams, H., West, J. B., and Farquhar, G. D.: Stable isotopes in leaf water of terrestrial plants, Plant Cell Environ., 39, 1087-1102, 2016.

Chapligin, B., Meyer, H., Friedrichsen, H., Marent, A., Sohns, E., and Hubberten, H.-W.: A high-performance, safer and semiautomated approach for the $\delta^{18} \mathrm{O}$ analysis of diatom silica and new methods for removing exchangeable oxygen, Rapid Commun. Mass Spectrom., 24, 2655-2664, 2010.

Chapligin, B., Leng, M. J., Webb, E., Alexandre, A., Dodd, J. P., Ijiri, A., Lücke, A., Shemesh, A., Abelmann, A., Herzschuh,
U., et al.: Inter-laboratory comparison of oxygen isotope compositions from biogenic silica, Geochim. Cosmochim. Acta, 75, 7242-7256, 2011.

Chen, G., Auerswald, K., and Schnyder, H.: ${ }^{2} \mathrm{H}$ and ${ }^{18} \mathrm{O}$ depletion of water close to organic surfaces, Biogeosciences, 13, 31753186, https://doi.org/10.5194/bg-13-3175-2016, 2016.

Chung, E.-S., Soden, B., Sohn, B. J., and Shi, L.: Uppertropospheric moistening in response to anthropogenic warming, P. Natl. Acad. Sci. USA, 111, 11636-11641, 2014.

Collura, L. V. and Neumann, K.: Wood and bark phytoliths of West African woody plants, Quat. Int., 434, 142-159, 2017.

Contreras, D. A., Robin, V., Gonda, R., Hodara, R., Dal Corso, M., and Makarewicz, C.: (Before and) After the Flood: A multiproxy approach to past floodplain usage in the middle Wadi el-Hasa, Jordan, J. Arid Environ, 110, 30-43, 2014.

Corbineau, R., Reyerson, P. E., Alexandre, A., and Santos, G. M.: Towards producing pure phytolith concentrates from plants that are suitable for carbon isotopic analysis, Rev. Palaeobot. Palyno., 197, 179-185, 2013.

Craig, H., and Gordon, L. I.: Deuterium and Oxygen 18 Variations in the Ocean and the Marine Atmosphere (Consiglio nazionale delle richerche, Laboratorio de geologia nucleare), 1965.

Crespin, J., Alexandre, A., Sylvestre, F., Sonzogni, C., Paillès, C., and Garreta, V.: IR laser extraction technique applied to oxygen isotope analysis of small biogenic silica samples, Anal. Chem., 80, 2372-2378, 2008.

Delattre, H., Vallet-Coulomb, C., and Sonzogni, C.: Deuterium excess in the atmospheric water vapour of a Mediterranean coastal wetland: regional vs. local signatures, Atmos. Chem. Phys., 15, 10167-10181, https://doi.org/10.5194/acp-15-101672015, 2015.

Dessler, A. E. and Davis, S. M.: Trends in tropospheric humidity from reanalysis systems, J. Geophys. Res.-Atmos., 115, D19127, https://doi.org/10.1029/2010JD014192, 2010.

Dodd, J. P. and Sharp, Z. D.: A laser fluorination method for oxygen isotope analysis of biogenic silica and a new oxygen isotope calibration of modern diatoms in freshwater environments, Geochim. Cosmochim. Acta, 74, 1381-1390, 2010.

Farquhar, G. D. and Cernusak, L. A.: On the isotopic composition of leaf water in the non-steady state, Funct. Plant Biol., 32, 293 303, 2005.

Farquhar, G. D. and Gan, K. S.: On the progressive enrichment of the oxygen isotopic composition of water along a leaf, Plant Cell Environ., 26, 801-819, 2003.

Fischer, E. M. and Knutti, R.: Robust projections of combined humidity and temperature extremes, Nat. Clim. Change, 3, 126130, 2013.

Gaj, M., Beyer, M., Koeniger, P., Wanke, H., Hamutoko, J., and Himmelsbach, T.: In situ unsaturated zone water stable isotope $\left({ }^{2} \mathrm{H}\right.$ and $\left.{ }^{18} \mathrm{O}\right)$ measurements in semi-arid environments: a soil water balance, Hydrol. Earth Syst. Sci., 20, 715-731, https://doi.org/10.5194/hess-20-715-2016, 2016.

Gat, J. R. and Bowser, C.: The heavy isotope enrichment of water in coupled evaporative systems, in: Stable Isotope Geochemistry: A Tribute to Samuel Epstein, edited by: Taylor Jr., H. P., O’Neil, J. R., and Kaplan, I. R., The Geochemical Society Special Publication No. 3, 159-168, 1991. 
Gibson, D. J. and Newman, J. A.: Festuca arundinacea Schreber (F. elatior L. ssp. arundinacea (Schreber) Hackel), J. Ecol., 89, 304324,2001

Grießinger, J., Bräuning, A., Helle, G., Hochreuther, P., and Schleser, G.: Late Holocene relative humidity history on the southeastern Tibetan plateau inferred from a tree-ring $\delta^{18} \mathrm{O}$ record: Recent decrease and conditions during the last 1500 years, Quat. Int., 430, 52-59, 2016.

Guillevic, M., Bazin, L., Landais, A., Stowasser, C., MassonDelmotte, V., Blunier, T., Eynaud, F., Falourd, S., Michel, E., Minster, B., Popp, T., Prié, F., and Vinther, B. M.: Evidence for a three-phase sequence during Heinrich Stadial 4 using a multiproxy approach based on Greenland ice core records, Clim. Past, 10, 2115-2133, https://doi.org/10.5194/cp-10-2115-2014, 2014.

Harris, I., Jones, P. D., Osborn, T. J., and Lister, D. H.: Updated high-resolution grids of monthly climatic observations - the CRU TS3.10 Dataset, Int. J. Climatol., 34, 623-642, 2014.

Held, I. M. and Soden, B. J.: Water Vapor Feedback and Global Warming, 1. Annu. Rev. Energy Environ., 25, 441-475, 2000.

Helliker, B. R. and Ehleringer, J. R.: Establishing a grassland signature in veins: ${ }^{18} \mathrm{O}$ in the leaf water of $\mathrm{C} 3$ and $\mathrm{C} 4$ grasses, P. Natl. Acad. Sci. USA, 97, 7894-7898, 2000.

Herbert, A. V. and Harrison, S. P.: Evaluation of a modern-analogue methodology for reconstructing Australian palaeoclimate from pollen, Rev. Palaeobot. Palynol., 226, 65-77, 2016.

Herwartz, D., and Pack, A.: The triple oxygen isotope composition of the Earth mantle and understanding variations in terrestrial rocks and minerals, Earth Planet. Sci. Lett., 390, 138-145, https://doi.org/10.1016/j.epsl.2014.01.017, 2014.

IAEA: A Laboratory Information Management System for Stable Hydrogen and Oxygen Isotopes in Water Samples by Laser Absorption Spectroscopy, User Manual and Tutorial, 2013.

Kondo, R., Childs, C., and Atkinson, I.: Opal phytoliths of New Zealand, Manaaki Whenua Press, 85 pp., 1994.

Kriticos, D. J., Webber, B. L., Leriche, A., Ota, N., Macadam, I., Bathols, J., and Scott, J. K.: CliMond: global high-resolution historical and future scenario climate surfaces for bioclimatic modelling, Methods Ecol. Evol., 3, 53-64, 2012.

Kumar, S., Milstein, Y., Brami, Y., Elbaum, M., and Elbaum, R.: Mechanism of silica deposition in sorghum silica cells, New Phytol., 213, 791-798, 2017.

Labuhn, I., Daux, V., Girardclos, O., Stievenard, M., Pierre, M., and Masson-Delmotte, V.: French summer droughts since $1326 \mathrm{CE}$ : a reconstruction based on tree ring cellulose $\delta^{18} \mathrm{O}$, Clim. Past, 12, 1101-1117, https://doi.org/10.5194/cp-12-1101-2016, 2016.

Landais, A., Barkan, E., Yakir, D., and Luz, B.: The triple isotopic composition of oxygen in leaf water, Geochim. Cosmochim. Acta, 70, 4105-4115, 2006.

Landais, A., Barkan, E., and Luz, B.: Record of $\delta^{18} \mathrm{O}$ and ${ }^{17} \mathrm{O}$-excess in ice from Vostok Antarctica during the last 150000 years, Geophys. Res. Lett., 35, L02709, https://doi.org/10.1029/2007GL032096, 2008.

Landais, A., Dreyfus, G., Capron, E., Masson-Delmotte, V., Sanchez-Goñi, M. F., Desprat, S., Hoffmann, G., Jouzel, J., Leuenberger, M., and Johnsen, S.: What drives the millennial and orbital variations of $\delta^{18}$ Oatm?, Quat. Sci. Rev., 29, 235-246, 2010a.

Landais, A., Risi, C., Bony, S., Vimeux, F., Descroix, L., Falourd, S., and Bouygues, A.: Combined measurements of ${ }^{17}$ Oexcess and d-excess in African monsoon precipitation: Implications for evaluating convective parameterizations, Earth Planet. Sci. Lett., 298, 104-112, 2010b.

Lavergne, A., Daux, V., Villalba, R., Pierre, M., Stievenard, M., and Srur, A. M.: Improvement of isotope-based climate reconstructions in Patagonia through a better understanding of climate influences on isotopic fractionation in tree rings, Earth Planet. Sci. Lett., 459, 372-380, 2017.

Lebamba, J., Vincens, A., Jolly, D., Ngomanda, A., Schevin, P., Maley, J., and Bentaleb, I.: Modern pollen rain in savanna and forest ecosystems of Gabon and Cameroon, Central Atlantic Africa, Rev. Palaeobot. Palyno., 153, 34-45, 2009.

Lehmann, M. M., Goldsmith, G. R., Schmid, L., Gessler, A., Saurer, M., and Siegwolf, R. T. W.: The effect of ${ }^{18}$ O-labelled water vapour on the oxygen isotope ratio of water and assimilates in plants at high humidity, New Phytol., 217, 105-116, 2018.

Levin, N. E., Raub, T. D., Dauphas, N., and Eiler, J. M.: Triple oxygen isotope variations in sedimentary rocks, Geochim. Cosmochim. Ac., 139, 173-189, 2014.

Lézine, A. M., New pollen data from the Sahel, Senegal, Rev. Palaeobot. Palyno., 55, 141-154, https://doi.org/10.1016/00346667(88)90082-6, 1988.

Li, S., Levin, N. E., and Chesson, L. A.: Continental scale variation in ${ }^{17} \mathrm{O}$-excess of meteoric waters in the United States, Geochim. Cosmochim. Acta, 164, 110-126, 2015.

Li, S., Levin, N. E., Soderberg, K., Dennis, K. J., and Caylor, K. K.: Triple oxygen isotope composition of leaf waters in Mpala, central Kenya, Earth Planet. Sci. Lett., 468, 38-50, 2017.

Liu, W., Liu, W., Li, P., Duan, W., and Li, H.: Dry season water uptake by two dominant canopy tree species in a tropical seasonal rainforest of Xishuangbanna, SW China, Agr.-Forest Meteorol., 150, 380-388, 2010.

Liu, W. J., Liu, W. Y., Li, J. T., Wu, Z. W., and Li, H. M.: Isotope variations of throughfall, stemflow and soil water in a tropical rain forest and a rubber plantation in Xishuangbanna, SW China, Hydrol. Res., 39, 437-449, 2008.

Luz, B. and Barkan, E.: Variations of ${ }^{17} \mathrm{O} /{ }^{16} \mathrm{O}$ and ${ }^{18} \mathrm{O} /{ }^{16} \mathrm{O}$ in meteoric waters, Geochim. Cosmochim. Acta, 74, 6276-6286, 2010.

Ma, J. F. and Yamaji, N.: Silicon uptake and accumulation in higher plants, Trends Plant Sci., 11, 392-397, 2006.

Madella, M., Alexandré, A., Ball, T., Group, I. W., et al.: International code for phytolith nomenclature 1.0, Ann. Bot., 96, 253260, 2005.

Majoube, M.: Fractionnement en oxygène 18 et en deutérium entre l'eau et sa vapeur, J. Chim. Phys., 68, 1423-1436, 1971.

Martín-Gómez, P., Barbeta, A., Voltas, J., Peñuelas, J., Dennis, K., Palacio, S., Dawson, T. E., and Ferrio, J. P.: Isotope-ratio infrared spectroscopy: a reliable tool for the investigation of plant-water sources?, New Phytol., 207, 914-927, 2015.

Miller, M. F., Greenwood, R. C., and Franchi, I. A.: Comment on "The triple oxygen isotope composition of the Earth mantle and understanding $\Delta^{17} \mathrm{O}$ variations in terrestrial rocks and minerals" by Pack and Herwartz, Earth Planet. Sci. Lett., 390, 138-145, 2015.

New, M., Lister, D., Hulme, M., and Makin, I.: A high-resolution data set of surface climate over global land areas, Clim. Res., 21, 1-25, 2002. 
Nogué, S., Whicher, K., Baker, A. G., Bhagwat, S. A., and Willis, K. J. Phytolith analysis reveals the intensity of past land use change in the Western Ghats biodiversity hotspot, Quaternary Int., 437, 82-89, 2017.

Oerter, E., Finstad, K., Schaefer, J., Goldsmith, G. R., Dawson, T., and Amundson, R.: Oxygen isotope fractionation effects in soil water via interaction with cations $(\mathrm{Mg}, \mathrm{Ca}, \mathrm{K}, \mathrm{Na})$ adsorbed to phyllosilicate clay minerals, J. Hydrol., 515, 1-9, 2014.

Orlowski, N., Pratt, D. L., and McDonnell, J. J.: Intercomparison of soil pore water extraction methods for stable isotope analysis, Hydrol. Process., 30, 3434-3449, 2016.

Pack, A. and Herwartz, D.: The triple oxygen isotope composition of the Earth mantle and understanding variations in terrestrial rocks and minerals, Earth Planet. Sci. Lett., 390, 138-145, 2014.

Passey, B. H., Hu, H., Ji, H., Montanari, S., Li, S., Henkes, G. A., and Levin, N. E.: Triple oxygen isotopes in biogenic and sedimentary carbonates, Geochim. Cosmochim. Acta, 141, 1-25, 2014.

Pasturel, M., Alexandre, A., Novello, A., Dièye, A. M., Wélé, A., Paradis, L., Cordova, C., and Hély, C.: Grass Physiognomic Trait Variation in African Herbaceous Biomes, Biotropica 48, 311320, 2016

Piperno, D. R.: Phytoliths: A Comprehensive Guide for Archaeologists and Paleoecologists (Rowman Altamira), 2006.

Rach, O., Kahmen, A., Brauer, A., and Sachse, D.: A dualbiomarker approach for quantification of changes in relative humidity from sedimentary lipid D / H ratios, Clim. Past, 13, 741757, https://doi.org/10.5194/cp-13-741-2017, 2017.

Ripullone, F., Matsuo, N., Stuart-Williams, H., Wong, S. C., Borghetti, M., Tani, M., and Farquhar, G.: Environmental Effects on Oxygen Isotope Enrichment of Leaf Water in Cotton Leaves, Plant Physiol., 146, 729-736, 2008.

Risi, C., Landais, A., Bony, S., Jouzel, J., Masson-Delmotte, V., and Vimeux, F.: Understanding the ${ }^{17} \mathrm{O}$ excess glacial-interglacial variations in Vostok precipitation, J. Geophys. Res.-Atmos., 115, D10112, https://doi.org/10.1029/2008JD011535, 2010.

Risi, C., Landais, A., Winkler, R., and Vimeux, F.: Can we determine what controls the spatio-temporal distribution of d-excess and ${ }^{17} \mathrm{O}$-excess in precipitation using the LMDZ general circulation model?, Clim. Past, 9, 2173-2193, https://doi.org/10.5194/cp-9-2173-2013, 2013.

Roden, J. S., Lin, G., and Ehleringer, J. R.: A mechanistic model for interpretation of hydrogen and oxygen isotope ratios in tree-ring cellulose, Geochim. Cosmochim. Ac., 64, 21-35, 2000.

Schmidt, M., Maseyk, K., Lett, C., Biron, P., Richard, P., Bariac, T., and Seibt, U.: Concentration effects on laser-based $\delta^{18} \mathrm{O}$ and $\delta^{2} \mathrm{H}$ measurements and implications for the calibration of vapour measurements with liquid standards, Rapid Commun. Mass Spectrom., 24, 3553-3561, 2010.

Schoenemann, S. W., Steig, E. J., Ding, Q., Markle, B. R., and Schauer, A. J.: Triple water-isotopologue record from WAIS Divide, Antarctica: Controls on glacial-interglacial changes in 17Oexcess of precipitation, J. Geophys. Res.-Atmos. 119, 2014JD021770, https://doi.org/10.1002/2014JD021770, 2014.

Schwab, V. F., Garcin, Y., Sachse, D., Todou, G., Séné, O., Onana, J.-M., Achoundong, G., and Gleixner, G.: Effect of aridity on $\delta^{13} \mathrm{C}$ and $\delta \mathrm{D}$ values of $\mathrm{C} 3$ plant- and $\mathrm{C} 4$ graminoid-derived leaf wax lipids from soils along an environmental gradient in
Cameroon (Western Central Africa), Org. Geochem., 78, 99109, 2015.

Scurfield, G., Anderson, C. R., and Segnit, E.: Silica in woody stems, Aust. J. Bot, 22, 211-229, 1974.

Sharp, Z. D., Gibbons, J. A., Maltsev, O., Atudorei, V., Pack, A., Sengupta, S., Shock, E. L., and Knauth, L. P.: A calibration of the triple oxygen isotope fractionation in the $\mathrm{SiO}_{2}-\mathrm{H}_{2} \mathrm{O}$ system and applications to natural samples, Geochim. Cosmochim. Acta, 186, 105-119, 2016.

Sherwood, S. C., Ingram, W., Tsushima, Y., Satoh, M., Roberts, M., Vidale, P. L., and O'Gorman, P. A.: Relative humidity changes in a warmer climate, J. Geophys. Res.-Atmos., 115, D09104, https://doi.org/10.1029/2009JD012585, 2010.

Stahl, C., Hérault, B., Rossi, V., Burban, B., Bréchet, C., and Bonal, D.: Depth of soil water uptake by tropical rainforest trees during dry periods: does tree dimension matter?, Oecologia, 173, 11911201, 2013.

Steig, E. J., Gkinis, V., Schauer, A. J., Schoenemann, S. W., Samek, K., Hoffnagle, J., Dennis, K. J., and Tan, S. M.: Calibrated high-precision ${ }^{17} \mathrm{O}$-excess measurements using cavity ring-down spectroscopy with laser-current-tuned cavity resonance, Atmos. Meas. Tech., 7, 2421-2435, https://doi.org/10.5194/amt-7-24212014, 2014.

Stevens, B., Brogniez, H., Kiemle, C., Lacour, J.-L., Crevoisier, C., and Kiliani, J.: Structure and dynamical influence of water vapor in the lower tropical troposphere, Surv. Geophys., 38, 13711397, 2017.

Suavet, C., Alexandre, A., Franchi, I. A., Gattacceca, J., Sonzogni, C., Greenwood, R. C., Folco, L., and Rochette, P.: Identification of the parent bodies of micrometeorites with high-precision oxygen isotope ratios, Earth Planet. Sci. Lett., 293, 313-320, 2010.

Surma, J., Assonov, S., Bolourchi, M. J., and Staubwasser, M.: Triple oxygen isotope signatures in evaporated water bodies from the Sistan Oasis, Iran, Geophys. Res. Lett., 42, 8456-8462, https://doi.org/10.1002/2015GL066475, 2015.

Surma, J., Assonov, S., Herwartz, D., Voigt, C., and Staubwasser, M.: The evolution of ${ }^{17} \mathrm{O}$-excess in surface water of the arid environment during recharge and evaporation, Sci. Rep., 8, 4972, https://doi.org/10.1038/s41598-018-23151-6, 2018.

Tanaka, R. and Nakamura, E.: Determination of ${ }^{17} \mathrm{O}$-excess of terrestrial silicate/oxide minerals with respect to Vienna Standard Mean Ocean Water (VSMOW), Rapid Commun. Mass Spectrom., 27, 285-297, 2013.

Welle, B. J. H. ter: On the occurrence of Silica grains in the secondary xylem of the Chrysobalanaceae, IAWA Bulletin, 2, 1929, 1976.

Treydte, K., Boda, S., Graf Pannatier, E., Fonti, P., Frank, D., Ullrich, B., Saurer, M., Siegwolf, R., Battipaglia, G., Werner, W., and Gessler, A.: Seasonal transfer of oxygen isotopes from precipitation and soil to the tree ring: source water versus needle water enrichment, New Phytol., 202, 772-783, 2014.

Tuthorn, M., Zech, R., Ruppenthal, M., Oelmann, Y., Kahmen, A., del Valle, H. F., Eglinton, T., Rozanski, K., and Zech, M.: Coupling $\delta^{2} \mathrm{H}$ and $\delta^{18} \mathrm{O}$ biomarker results yields information on relative humidity and isotopic composition of precipitation - a climate transect validation study, Biogeosciences, 12, 3913-3924, https://doi.org/10.5194/bg-12-3913-2015, 2015. 
Uemura, R., Barkan, E., Abe, O., and Luz, B.: Triple isotope composition of oxygen in atmospheric water vapor, Geophys. Res. Lett., 37, L04402, https://doi.org/10.1029/2009GL041960, 2010.

Valley, J. W., Kitchen, N., Kohn, M. J., Niendorf, C. R., and Spicuzza, M. J.: UWG-2, a garnet standard for oxygen isotope ratios: Strategies for high precision and accuracy with laser heating, Geochim. Cosmochim. Acta, 59, 5223-5231, 1995.

Wahl, E. R., Diaz, H. F., and Ohlwein, C.: A pollen-based reconstruction of summer temperature in central North America and implications for circulation patterns during medieval times, Glob. Planet. Change, 84-85, 66-74, 2012.

Webb, E. A. and Longstaffe, F. J.: The oxygen isotopic compositions of silica phytoliths and plant water in grasses: Implications for the study of paleoclimate, Geochim. Cosmochim. Acta, 64, 767-780, 2000.

Webb, E. A. and Longstaffe, F. J.: Climatic influences on the oxygen isotopic composition of biogenic silica in prairie grass, Geochim. Cosmochim. Acta, 66, 1891-1904, 2002.

Webb, E. A. and Longstaffe, F. J.: The relationship between phytolith- and plant-water delta O-18 values in grasses, Geochim. Cosmochim. Acta, 67, 1437-1449, 2003.
Webb, E. A. and Longstaffe, F. J.: Identifying the $\delta{ }^{18} \mathrm{O}$ signature of precipitation in grass cellulose and phytoliths: Refining the paleoclimate model, Geochim. Cosmochim. Acta, 70, 2417-2426, 2006.

Welp, L. R., Lee, X., Kim, K., Griffis, T. J., Billmark, K. A., and Baker, J. M.: $\delta^{18} \mathrm{O}$ of water vapour, evapotranspiration and the sites of leaf water evaporation in a soybean canopy, Plant Cell Environ., 31, 1214-1228, 2008.

Wernicke, J., Grießinger, J., Hochreuther, P., and Bräuning, A.: Variability of summer humidity during the past 800 years on the eastern Tibetan Plateau inferred from $\delta^{18} \mathrm{O}$ of tree-ring cellulose, Clim. Past, 11, 327-337, https://doi.org/10.5194/cp-11327-2015, 2015.

White, F., Unesco, and Office, U.N.S.-S.: The vegetation of Africa: a descriptive memoir to accompany the Unesco/AETFAT/UNSO vegetation map of Africa (Unesco), 1983.

Winkler, R., Landais, A., Sodemann, H., Dümbgen, L., Prié, F., Masson-Delmotte, V., Stenni, B., and Jouzel, J.: Deglaciation records of ${ }^{17} \mathrm{O}$-excess in East Antarctica: reliable reconstruction of oceanic normalized relative humidity from coastal sites, Clim. Past, 8, 1-16, https://doi.org/10.5194/cp-8-1-2012, 2012. 